\title{
KANUNA AYKIRI TÜZÜKLER KARŞISINDA MAHKEMELERIN DURUMU
}

Doçent Turhan FEYZiOGLU

Anayasamizin 52 nci maddesi Bakanlar Kuruluna "kanunların uygulanışını göstermek yahut kanunun emrettiği işleri belirtmek üzere, içinde yeni hükümler bulunmamak ve Danıştayın incelemesinden geçirilmek şartıyla" tüzükler yapmak selâhiyetini vermiştir. Yürütme organına böyle bir selâhiyetin tanınmasını gerektiren sebepler malûmdur: Kanun vâzıı bilhassa teknik mahiyet arzeden mevzularda ancak ana hükümleri tesbit edebilir; teferruata müteallik noktalarn tanzimini yürütme organına bırakmağa mecburdur. Ana prensiplere nisbetle, teferruata müteallik olan bu hükümlerin daha sık değiştirilmesi icab eder. Bazı meselelerin tanziminde büyük bir sür'ate, bazılarında da gizliliğe ihtiyaç duyulur. İște bütün bu mulâhazalar her memlekette, yürütme uzvuna az çok geniş bir tanzim selâhiyeti tanınmasını zaruri kılmış ve devletçilik cereyanları bu selâhiyetin sınırlarını gitgide genişletmiştir. Bu yazıda, hükûmete tanınmıs olan tanzim selâhiyetinin lüzumu, sinırları, mahiyeti uzun uzadıya münakaşa edilecek değildir. Bütün bu noktalar hakkında Ord. Prof. Ali Fuat Başgil'in "Türkiye Teşkilât hukukunda Nizamname mefhumu ve Nizamnamelerin mahiyeti ve tâbi olduğu hukukî rejim" adlı geniş etüdü (1) ile hocam Frof. Ragıp Sarıca'nın "Türkiye'de icra uzvunun tanzim selâhiyeti" adlı kıymetli eserine başvurulabilir. (2) Burada bizim yapmak istediğimiz şey Türk doktrininde ötedenberi çok münakaşalı olan şu meseleyi, bazı mahkeme içtihatlarının da ışı̆ı altında, yeniden ele almaktan ibarettir: Türk mahkemeleri bir tüzüğün kanuna aykırı olup olmadığını tetkik edebilirler mi? Kanuna aykırı bir tüzük karşısında adlî ve idarî kazanın durumu nedir?

Hemen şu noktayı belirtelim ki, bu mevzuda, tanınmış hukukçularımız arasında görüș ayrılığı vardır. Anayasamız 52 nci maddesinin son fıkrasında: "Tüzüklerin kanunlara aykırılığı ileri sürüldükte bunu çözüm

(1) Cemil Bilsele Armağan, tstanbul, 1939. (Etüdün tamaminı Ali Fuat Başgil'in Hukukun ana mesele ve mïesseseleri adı eserinde de bulmak kabildir. Hukukî Bilgiler mecmuası tarafından da kısmen iktibas edilmiştir. 1939, sayı 9-117, s. 7046)

(2) Bk. keza, S. S. Onar, Idare Hukuku, c. 1, ikinci bası, tst. 1945, s. 204 ve müt. 
yeri T. B. M. M. dir. " hükmünü koymuştur. Bu hükmün tefsiri hususunda hukukçularımızın ileri sürdükleri çeşitli fikirleri izah ettikten sonra, kendi düşüncelerimizi açıllyacağı. Fakat, meselenin Türkiyedeki hal şeklini ele almadan önce, kısa ve sathî de olsa, mukayeseli bir tetkik yaparak bazı yabancı memleketlerde kanuna aykırı tüzüklerin tâbi olduğu hukukî rejimi gözden geçirmekte fayda vardır.

Yabancı hukuk nizamlarına bakınca, tüzüklerin kanuna ve Anayasaya uygunluğunu temin etmek için her tarafta kazaî murakabeye yer verildiği göze çarpar. Türkiyedeki durumu incelerken daha etraflı olarak göreceğimiz gibi, kazaî murakabe başlıca iki şekilde tecelli edebilir:

a) Bir tüzügün kanuna aykırı olduğu ileri sürülerek, bu tüzüğün iptali, ortadan kaldırılması istenebilir. Bu takdirde "dâva yoluyla murakabe" den bahsedilir (par voie d'action).

b) Bir kimse, esasen görülmekte olan bir dâva münasebetiyle, hâdiseye tatbik edilmek istenilen bir tüzügün kanuna aykırı olduğunu ileri sürebilir. Mahkeme, aykırılık iddiasını haklı bulursa, tüzügü iptal etmemekle berabere o dâvada tüzüğün hükmünü tatbikten imtina eder. Buna da "defi yoluyla murakabe" adi verilir. (par voie d'exception).

Yabancı hukuk nizamlarında, "đâva yoluyla murakabe" her zaman kabul edilmese bile, hiç değilse asgarî bir teminat olarak "defi yoluyla murakabe" umumiyetle kabul edilmektedir. Kanunlarin Anayasaya uygunluğunun kazaî murakabeye tâbi olup olmadığı meselesinin kesin olarak halledilmediği memleketlerde dahi, kanunlar için her türlü kazâ̂ murakabeyi reddeden müellifler bile, tüzüklerin kazaî murakabeden hariç tutulmalarını asla kabul etmemektedirler. Meselâ Fransada ve Weimar Almanyasında durum böyyledir. Fransada, tüzüklerin kanuna aykırılı̆̆ı hem dâva yoluyla, hem de defi yoluyla ileri sürülebilir. (3) Fransa'da bu geniş kazaî murakabe birden bire değil, uzun bir tekâmül neticesinde doğmustur. Fransız Devlet Şûrası ilk zamanlarda devlet reisi tarafından imza edilen tüzüklerin, kazaî murakabeye tâbi tutulamıyacağı içtihadına saplanmiștır. Fakat 1830 dan itibaren, devlet reisinin siyasî ehemmiyeti azalıp Parlâmentonun mevkii kuvvetlendikçe, içtihatlarda bir değişme belirmiş ve 1845 yılında devlet reisinin imzasını taşıyan tüzüklerin iptaline müteallik ilk Devlet Şûrası kararları ortaya çıkmıştır.

Fakat "réglements d'administration publique" adi verilen ve ancak Devlet Şûrası Umumî Heyetinin mütalâası alınmak suretiyle yapilabilen tüzükler (bizdeki tüzük mefhumuna tekabül edenler asıl bunlardır) 1907

(3) R. Alibert, Le contrôle juridictionnel de l'administration au moyen du recours pour excès de pouvoir, Paris, 1926, s. 17.

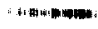


yllna kadar yasama kuvvetinin delegasyonuna müstenit sayllarak, kazaî murakabeden hariç tutulmuslardır. Nihayet 6 Ocak 1907 tarihli bir kararla, Devlet Şûrası, bütün tüzükler aleyhine iptal dâvası açılabileceğini kabul etmiştir. (4) Gerçi ikinci cihan harbini takip eden son intikal yillarinda Fransız Devlet Şûrası, Fransız Millî Kurtuluş Komitesi (CFLN) ve Fransa Cumhuriyeti muvakkat hükümeti (GPRF) tarafından çıarılan emirnameler aleyhine hiç bir suretle dâva açlamıyacağına karar vermiştir. Fakat unutmamak lâzımdır ki, bunlar icra uzvunun tanzim selâhiyetine giren tasarruflar değil, Şûranın da belirttiği gibi, teşriî mahiyette tasarruflardir. (5)

Fakat Fransa'da, doğrudan doğruya iptal dâvası açmak suretiyle kanuna aykırı bir tüzüğün iptal ettirilebilmesi kâfi görülmemiştir. İptal dâvaları gayet kısa bir müddete tâbidir. Bu müddet geçtikten sonra, kanuna aykirı bir tüzük idarî mahkemeleri olsun, adlî mahkemeleri olsun bağlıyacak mıdır? Hayır. Bu takdirde de, kazaî murakabenin ikinci şekli, yani "def'i yoluyla murakabe" imdada yetişmektedir. Gerek idarî, gerek adlî mahkemelerin, görmekte oldukları bir dâva münasebetiyle, kanuna aykırı bir tüzüğü tatbikten imtina edebilecekleri yolunda Fransız mahkemelerinin kökleşmiş içtihatları vardır. Doktrin de bu hususta aşağı yukarı müttefiktir. (6) Mahkemelerin bu selâhiyeti, kaideler hiyerarşisinde kanunun tüzüğe nazaran daha üstün bir yer işgal etmesinin tabiî neticesi sayılmaktadır. Ancak, Fransız mahkemelerinin bu selâhiyeti tam bir şekilde kullanmağa başlamaları da

(4) Bu içtihat değişikliğinin nașl bir tekâmül neticesinde yavaş yavaş hazıriandığını G. Jèze gayet iyi izah etmektedir. Bk. Les principes généraux du droit administratif, 3 ème éd., Paris, 1925, T. 1, s. 379 ve müt.; - 6 Ocak 1907 kararı hakkında bütün klâsik eserlerde malumat vardır. Bk. meselâ H. Berthélemy, Traité élémentaire de droit administratif, 13 ème ed., Paris, 1933, s. 126. - Bk. keza Sirey, 1908. III. 1, Comp. de chemins dee fer; Sirey 1914. III.. 36, Omer Decugis; Sirey, 1914. III. 78, Seurin et Lenoir kararları.

(5) Fr. Devlet Şarası, 22 Şubat 1946, Botton, Sirey, 1946, III. 56. - Kararın hülâsası Revue de Droit Public'de de çıkmıştır, avril-juin 1947, s. 205.

(6) Bk. Meselâ Duguit, Manuel de droit constitutionnel, 4 ème éd., Paris, 1923. s. 305; Berthélemy, s. g. e., s. 123 ve müt. ve notlar; J. Bonnecase, Introduction $\hat{a}$ l'étude du droit, 3 ème éd., Paris, 1939, s. 143 ve müt.; H. Berthélemy, Défense de quelques vieux principes: la loi et le règlement, Mélanges Hauriou, s. 821 ve müt.; Waline, Manuel élémentaire de droit administratif, 2 ème éd., Paris 1939, s. 318 ve müt.; bilhassa, A. Mestre, Recherches sur l'exception d'illégalité, Mélanges Hauriou. s. 567 ve müt.; Ch. Crozat, Devlet Şurası: yasaya uygunluk mercii, Mülkiye mecmuası, 1934, sayı 38, s. 22 - 23; mahkeme içtihatlarının tipik bir örneği olarak, Fran. sız Temyiz Mahkemesi Hukuk dairesinin 24 ekim 1917 tarihli Guillou karan gös. terilebilir: blk. Sirey, 1918.1.193. 
uzunca bir teltâmülün eseri olmuștur. Fransa'da idare ile adliyenin aymlı̆̆ gayet barizdir. Adliyeyi idarenin işlerine müdahaleden meneden çok sarih metinler vardır. (16-24 Ağustos 1790 tarihli kanun, m. 13, fasıl II. 1791 Anayasası, m. 3, böl. V, fasıl III; Ceza kanunu, m. 127). Bütün bu hükümlere rağmen, A. Mestre'in sözü geçen etüdünde gayet etraflı bir şekilde anlattığı gibi, adlî mahkemeler ad’m adım bu selâhiyeti elde etmişlerdir.

Fransız mahkemeleri bu murakabeyi fiilen yapmakta oldukları bir sirada, 28 nisan 1832 tarihli kanunla Ceza kanununa ilâve edilen bì hüküm (m. 471, kent 15) mahkemelerin bu içtihadını takviye etmiștir. $\mathrm{Bu}$ bentte "kanun dairesinde yapılmıs tüzüklere aykırı hareket" edenler'den bahsedilmektedir. Bundan mahkemelerin bir tüzüğün "kanun dairesinde" yapılıp yapılmadığını kontrol edebilecekleri neticesi çkarılmaktadır. Gerçi uyuşmazlık mahkemesinin çok meşhur bir kararı, 16 haziran 1923 tarihli Septfonds kararı fikirlerde biraz tereddüt uyandirmis. tır. Bu karara göre adlî mahkemeler, yürütme uzvu tarafından yapılan tüzükleri tefsir edebilirler, fakat kanuna uygun olup olmadiklarmin murakabe edemezler. Aksi takdirde adliye ile idare arasındaki ayrıllk ihlá ? edilmiş olur. Müellifler, uyuşmazlık mahkemesinin bu kararına rağmen, Temyiz mahkemesinin, tüzüklerin kanuna uygunluğunu defi yoluyja tetkike devam ettiğini belirtmekte ve Septfonds kararını şiddetle tenkit etmektedirler (7).

Gerçekten, hukuk kaidelerini hâdiselere tatbik etmekle mükellef olan kazai mercilerin, kanunun hükmünü tüzüğe tercih etmelerinden daha tabiî ve mantıkî bir şey olamaz. Bu mantıkî kaide, bazan anayasalar. da sarahaten yer almıştır, bazan da anayasaların sükûtu karșısında mahkeme içtihatları ve doktrin meseleyi halletmiştir. Meselâ 1831 tarihli Belçika anayasası, mahkemelerin ancak kanunlara uygun olan tïzükleri tatbik edebileceklerini açıkça söylemiştir (m. 107). 1 ekim 1920 tarihli Avusturya anayasası ise, kanunların anayasaya uygunluğunu kontrol etmek üzere kurduğu anayasa mahkemesine (Verfassungsge. richtshof) tüzüklerin kanunlara uygunluğunu murakabe etmek selâhiyetini de sarahaten tanımıştır. Kelsen, Avusturya anayasa mahkemesi

(7) Ch. Crozat, s. g. e., s. 23; Bonnecase, s. g. e., s. 144; Berthélcmy, Traite élémentaire..., s. 124; Défense de quelques..., Mélanges Hauriou, s. 825; A. Mestr., s. g. e., Mélanges Hauriou, s. 591 - 595; Yalnız Waline, adlî mahkemelerin ancak ceza hukuku sahasında, zabıta tüzüklerinin kanuna aykırılığını tesbit edebilecek!n. rini iddia etmekte ve ceza kanununun 471 inci maddesinin 15 inci bendine dayarmaktadir. Diğer sahalarda, Septfonds kararı gereğince, murakabeyi ancak idarî mah kemeler yapabilecektir (Waline, s. $y$. c., s. 319 ve s. 66). 
hakkında yazdığı bir makalede (8), modern devletlerde tüzüklerin kanunlara uygunluğunu murakabe selâhiyetinin umumiyetle bütün mahkemelere tanınmış olduğunu ve mahkemelerin, rüyet etmekte oldukları hâdisede, kanuna aykırı gördükleri bir tüzüğü tatbikten imtina edebileceklerini belirttikten sonra, Avusturya federal anayasasınin, hukuk birliğini ve hukuk emniyetini sağlamak gayesiyle, daha radikal bir hal şekli kabul ettiğini söylüyor: Bir mahkeme, bir tüzüğün kanuna aykurı olduğu kanaatına varırsa (sadece taraflardan birinin aykırılık defini. ileri sürmesi kâfi değildir), dâvayı durdurur ve anayasa mahkemesinden tüzüğün iptalini ister. Mahkeme, tüzügüun tamamen mi, yoksa kısmen mi ilgasını istediğini bildirmeğe mecburdur. Anayasa mahkemesi tüzüğü kanuna aykırı görerek iptal ederse mahkeme artık tüzüğü tatbik edemez. Alssi takdirde tüzüğe göre karar verir. Kelsen, bu usulün başka memleketlerde bütün mahkemelere tanınmış olan umumî murakabe selâhiyetine nazaran bir tahdit teşkil ettiğini de ilâve etmektedir (9).

1920 tarihli Çekoslovakya anayasasinda ise, kanunlarm anayasaya uygunluğu hususunda karar vermek üzere hususî bir mahkeme teşhil edilmekle beraber tüzüklerin kanuna uygunluğunu murakabe selâhiyeti umumî mahkemelerden alınmamıştır (10).

(8) Hans Kelsen, Verfassungs - und Verwaltungsgerichtsbarkeit im Dienste dss Bundesstaates nach der neuen österreichischen Bundesverfassung vom 1 oktober 1920 (Zeitschrift für Schweizerisches Recht, Neue Folge 42, 1923, s. 196 - 197).

(9) Dolfuss rejimi ve Alman işgali altında ortadan kalkmış olan Anayasa MaLkemesi, ikinci dünya harbinden sonra doğan yeni Avusturyada tekrar kurulmuştur. Avusturya anayasa mahkemesine müteallik başlıca hükümler 1920 tarihli Avusturya anayasasının 137 - 148 inci maddeleri ile 1930 tarihli kanundadır. En son metinler ise şunlardır: 9 ekim 1946 tarihli anayasa tadilâtı (Bundesgesetzblatt für die Republik österreich, 24 aralı 1946, No. 211); Anayasa mahkemesinin kurulus ve işleyişine dair 1930 tarihli kanunu değiştiren 12 ekim 1945 tarihli muvakkat kanun (Staatsgesetzblatt..., 31 ekim 1945, no. 209), Anayasa mahkemesinin çalışma usuilerini gösteren tüzük (Bundesgesetzblatt..., 3 aralık 1946, no. 202). (Bu metinleri bize temin etmek lâtfunda bulunan değerli hukukçu ve Siyasal Bilgiler Okulu Almanca öğretmeni Dr. Silberknopf'a teşekkürü borç biliriz). Ikinci Dünya harbinden sonra yeniden kurulan Anayasa mahkemesinin başkanlığma Viyana Üniversitesi Profesörlerinden Ludwig Adamowich getirilmiştir. Milletlerarası tdarî tlimler Enstitüsünün bu yıl yaptı̆̆ı kongre için profesör taraf̂nđan Avusturya Anayasa Mahkemesi hakkında şayanı dikkat bir rapor hazırlanmıs ve tevzi edilmiştir. Raporca da ifade edildiği gibi, Avusturya Anayasa Mahkemesinin murakabesi kâğıt üstünde kalmamıştır. Yine sayın Dr. Silberknopf'un getirmek lâtfunda bulunduğu "Burdesgesetzblatt'lara göre, kanunlara aykırı tüzükler sık slk iptal edilmektedir. (Bk. meselâ, 7 eylal 1948, no. 181 - 182; 15 ocak 1949 , no. 13 ).

(10) Midhat bey: Teşkilâtı Esasiye Kanununa münafi ahkâmı ihtiva eden kavanin hakkında kazấ murakabe meselesi, $t H F M, 1927$ sene: 4, say1 28, s. 424. 
İsviçrede de, mahkemeler federal kanunlarm anayasaya uygunliğunu kontroldan anayasanın 113 üncü maddesiyle sarih surette menedilmiş oldukları halde, tüzüklerin kanuna uygunluğunu murakabe edebilmektedirler. Maruf İsviçreli âmmeci Fleiner, bu usulün Fransa ve Aimanyada da kabul edildiğini ve böyle bir murakabenin tabî̀ olduğunu tasrih etmektedir (11).

Gerçekten Almanyada da, Weimar rejiminde, kanunların anayasaya uygunluğunun kazaî murakabesi meselesi fikir ve içtihat ihtilâflaruna yol açtığı halde, tüzüklerin kanuna uygunluğunu murakabe etmek hususunda bütün mahkemelerin selâhiyetli oldukları münakașasız kabul edilmiştir. Mahkemeler de bu hususta hiç bir tereddüt göstermemişler$\operatorname{dir}(12)$.

Romanyada, 1923 anayasası ile, kanunların anayasaya uygunluğınu kontrol etmek için hususî bir usul ihdas edilerek, bu murakabenir Temyiz Mahkemesi umumî heyetine tevdi edildiği malûmdur. Tüzủkierin kanuna aykırılığını murakabe selâhiyetinin de Umumî Heyete mi, yoksa bütün mahkemelere mi ait olduğu münakaşa edilmiş; bazı terer!. dütlerden sonra, Temyiz mahkemesi tüzüklerin kanuna ve anayasaya uygunluğunu tetkik selâhiyetinin münhasıran Temyiz Mamkemesi Umumî Heyetine ait olmayıp, bütün kazaî mercilerin bu murakabeyi yapabileceklerine karar vermiştir (13).

Netice olarak diyebiliriz ki, hukuka bağlı devlet fikrinin yerleşmi is olduğu garp memleket́lerinde tüzülrlerin kazaî murakabesi meselesi münakaşa konusu olmaktan çımıstır. Mahkemelerin kanuna aykırı tiizükleri tatbik etmiyecekleri hususunda tam bir fikir birliği, bir "commi." nis opinio" mevcuttur. (Bk. N. Biert, s. g. e., s. 2).

Meinleketimize gelince: Anayasamızin 52 nci maddesinin son fik-

(1) F. Fleiner, Anme huicukunda büyük harpten sonraki istihaleler, Hukuk tlmini Yayma Konferansları: 9, Ankara 1936, s. 7; Fleiner, Einzelrecht und öffentliches interesse, Zweiter Abdruck, Tübingen, 1925, s. 17 - 19; Isviçre hakkında bak. keza, Dr. Dietrich Schindler, Die Verfassungsgerichtsbarkeit in den Vereinigten Staaten von Amerika und in der Schweiz (Zeitschrift fïr Schweizerisches Recit N. F. 44, s. 47); Claudle du Pasquier, Introduction à la philosophie du Droit. 2 ème éd., s. 48. Nicolo Biert, Die Prüfung der Verfassungsmaessigkeit der Gesetze durch den Richter, Bern, 1933, s. 2 ve 56.

(12) Bk. Anschütz, Die Verfassung des Deutschen Reichs rom 11 August 1919, Achte Auflage, Berlin, 1928, s. 216 - 217.

(13) Tafsilât için bk. Georges Alexiano, La suprématie de la constitution assulị̂t par les juges en Roumanie, Mélanges Paul Negulesco, București 1935. s. 25 - 27. 
rası yukarda söylediğimiz gibi bir ihtilâf kaynağı olmaktadır (14). Ele aldığı her mevzuu büyük bir titizlikle ince ince işleyen kıymetli hocam Prof. Ragıp Sarıca, zikrettiğimiz eserinde, Türk hukukçularının bu husustaki fikirlerini birer birer nakletmiș ve bunları tenkit süzgecinden geçirerek kendi düşüncelerini açıklamıştır.

Biz de, yapılmış bir işi tekrarlamak pahasına da olsa, kendi düşüncelerimizi açıklamadan önce, bu mevzuda ileri sürülen başlıca fikirleri tarih sirasiyle nakletmeği, vuzuh bakımindan, faydalı görüyoruz. But arada muhterem Sarıcanın zikrettiği müelliflerin listesine bir kaçını daha ilâve ederek doktrin tablosunu tamamlamağa çalıșacağız.

52 nci maddenin son fıkrasinı tefsir eden müelliflerden bazıları, mahkemelere tüzüklerin kanuna uygun olup olmadığmı tetkik selâhiyetini asla tanımamaktadırlar. (İstanbul Hukuk Fakültesi eski Profesörlerinden Midhat, Ordinaryüs Profesör Mustafa Reşit, Profesör Charles Crozat ve Prof. Ragip Sarıca bu fikirdedirler).

Bazlarna göre ise, 52 nci madde mahkemeleri, tüzüklerin kanuná uygunluğunu murakabeden mutlak surette menetmiyor, ancak bu mirakabenin "doğrudan doğruya", "re'sen", "dâva yoluyla" yapilamiyacağını gösteriyor.( Profesör Muslihiddin Adil, Talât Kaâmil, Ordinaryüs Profesör Ali Fuat Başgil, Profesör Bülend Nuri Esen, Doçent Bahri Saveı bu fikirdedirler). İstanbul Hukuk Fakültesi idare hukuku Ordinar. yüs Profesörü Sıddık Sami Onar, bu iki telâkkinin arasındia bir yol tutmaktadir.

Muhtelif guruplara ayırdığımız bu müelliflerin fikirlerini, biz de Sarica gibi tarih surasiyle nakledelim.

1 - İstanbul Hukuk Fakültesinin eski idare hukuku müderrisi Muslihiddin Adil beye göre; "Bu maddenin tefsiri hususunda bir tefrik yapmalı; meseleyi afâkî olarak düșïnecek olursak, yani bir nizamnamenin kanuna muvafakatı hususunun anlaşlması için, tefsiri idare makamatınca veya eşhas tarafından talep olunduğu takdirde bu hususta cevap vermek selâhiyeti B. M. M. nindir. Fakat mesele enfüsî noktai nazardan ve meselâ mahkeme huzurunda bir dâvanın takibi sırasında mevzuubahis olmuş ise, bu takdirde hâkimin selâhiyeti şüphesizdir. (Meselâ kănuna gayrı muvafık bir nizamname ile tarhedilmiş her hangi bir resmi

(14) Bizim 52 nci maddenin son fikrasını andıran bir hükme eski Prusya Devletinin 1850 tarihli anayasasının $106 \mathrm{ncl}$ maddesinde rastlanmaktadir (Eleines, s. $g . e .$, s. 7 ). 
vermediğinden nâși takibata maruz kalan bir ferdin müracaatı böyledir)" (15).

2 -- Ord. Prof. Crozat, sonradan kanaatını değistirmis olmakla beraber "kaniniarm anayasaya uygunluğunu kazaî murakabesi" meselesi üzerinde Wîhat beyle aralarında cereyan eden ilmî münakaşa esnasinda, Muslinidin Adil beyin yukardaki mütalâasını naklettikten sonra: "52 nei maddenin tefsiri hususunda bilâ tereddüt Muslihiddin Adil beyin fikrine ișinak ettiğini" söylemiştir (16).

3 -- "Kanunların anayasaya uygunluğunun kazaî murakabesi" me. selesi etrafinda Prof. Crozat ile aralarında cereyan eden münakaşa esnasinda müderris Midhat bey aksi tezi tutmuştur: Ona göre, 52 nci maddenin son flkrası gayet sarih olup her hangi bir tefrik yapmağa müsait değildir. Fıkranın hükmü mutlaktır. Türk hâkiminin nizamnameleri kanuna muvafakat ve ademi muvafakat noktai nazarından tetkik edemiyeceği muhakkaktır. Şu noktayı belirtelim ki, Midhat bey Meclis müzakerelerinden mâna ȩıkarmağa kalkışılmasına da taraftar değildir. Böyle bir hareket "asli birakup, fer'e gitmek" olur (17).

4 - Crozat ve Midhat bey tarafindan yaplan nakillere nazaran, Ord. Prof. Muammer Raşit Sevig'in de 52 nci maddeyi Midhat bey gibi tefsire mütemayil olduğu anlaşlmaktadır (18). Fakat kendi kaleminden çıkmamıs bir yazıda müphem surette yapılan bazı nakillere istinaden muhterem âlimin 52 nci maddeyi Midhat bey gibi anladığına kat'î surette hükmetmek bizce imkânsızdır.

5 - Bu arada, Midhat bey ile Ch. Crozat arasmdaki ilmî münakaşaya doğrudan doğruya katılmamıs olmakla beraber, sayın Ord. Prof. Mustafa Reşit de, bir yazısında, kanunların anayasaya uygunluğunun kazaî murakabesi meselesine dokunmuştur. Yirmi bir yll önce (1927 de) kaleme alınmış olan bu yazıdan, sayın ilim adamımızın, o tarihte, 52 nc: maddeyi Midhat bey gibi anlamağa mütemayil olduğu anlaşlmaktadır. Sayın M. R. Belgesay, bizde hâkimlerin defi yoluyla kanunların anayasaya uygunluğunu murakabe edemiyeceklerini söyledikten sonra, delil makamında, anayasanın 52 nci maddesini zikretmekte ve evleviyet kaidesine dayanmaktadir. “... Kanunu esaside hilâfina sarahat olmasa idi, içti-

(15) Nakleden Charles Crozat, "Türk hâkimi kavaninin Tessilâtı Esasiyeye tevafuk veya adcmi tevafukunu takdir hakkin haiz midir?.. IHFM, 1927, sene 5 , say1 33 , s. $980-981$.

(16) Ch. Crozat, s. g. є., IHFM, 1927, sene 5, sayı 33, s. 980.

(17) Midhat, "Tesskilatı Esasiye Kanununa münafi ahkâmı ihtiva eden kanunlar üzcrinde bisde kazaî murakabe meselesi, IHFM, 1928, sene 6, sayı 35, s. 1111-1112.

(18) Ch. Crozat. s. g. e., IHFM, 1927, sene 5, sayı 33, s. 971 
hat ile mahkemelerin bu selâhiyetini kabul lâzım gelecek idi. Fakat bize göre 52 nci maddenin delâleti kâfidir" (19).

6 - Prof. Crozat, yukårda izah edilen görüşünü sonradan terketmiştir. 1934 yllinda Mülkiye Mecmuasında çıkan bir makalesinde, şu fikirleri ileri sürmektedir:

a) Fransada nizamnameler aleyhine Devlet Sûrasında doğrudan doğruya iptal dâvası açlabildiği halde, Türkiyede 52 nci madde buna manidir.

b) Fransada, bundan başka, ikinci bir murakabe mevcuttur: Bütün mahkemeler bir nizamnamenin kanuna aykurılı̆̆ı yolunda ileri sürïlen defileri tetkik edebilirler. Acaba Türkiyede de böyle bir murakabe kabiu midir? "Yoksa, Devlet Şûrası veya hukuk mahkemeleri, yasaya uygurluk meselesi B. M. M. tarafından halledilinceye kadar hükmü tehir mi etmelidirler? Bize öyle geliyor ki, ku ikinci şekil metinlerin hakikî tefsiridir. Vazı kanunun, nizamnamelerin kontrolünü yalnız Büyük Millet Meclisine birakmak istediği anlaşlmaktadır" (20). 1934, sayı 38, s. 25. - Bk. keza, Sarıca s. g. e., s. 98 - 99.

7 - Prof. Crozat'nın diğer cepheye geçmesinden az sonra, Dr. Talât Kâmil, Muslihiddin Adil beyin tezini benimseyerek, Türk hâkimlerinin tiizükleri iptal edemiyeceklerini, fakat kanunsuzluk defini tetkike pekâlâ selâhiyetli olduklarm ileri sürüyor (21).

8 - Bu iki tez çarpışmakta iken, Ord. Prof. Siddık Sami Onar, İzmir Baro Dergisinde "Nizamname ve talimatnameler" adl bir makale neşrederek iki zit kanaatı telif eder gibi görünen bir fikir ortaya atıyor. "Nizamnamelerin kavanine mugayereti iddia olundukta bunun mercii halli B. M. M. dir. Binaenaleyh nizamnamelere karşı, diğer idarî muamele ve tasarruflar için açık olan itiraz yollarına müracaat edilemez. Meselâ Devlet Şûrasında bir iptal dâvası ikame olunamaz. Maddeten teşrî̀ bir tasarruf olan nizamnameleri İcra Vekilleri Heyeti tarafından Meclise vekâlet ve izafet suretiyle yapılmış birer tasarruf saymak mümkündür. Nizamnamelerin bu mahiyeti, 52 nci maddenin 3 üncü filkrasındaki sarahat, nizamnamelerin kanunlara mugayereti iddiasını ne idare ve ne de adliye mahkemelerinin tetkik edemiyeceğini göstermekle beraber, bu kaidenin iki istisnası mevcuttur" dendikten sonra, şeklî şartları tamam olmayan tüzüklerin mahkemelerce tüzük telâkki edilemiyeceği belirtilmekte ve bizi asıl ilgilendiren "maddî aykırılık" hususunda da şöyle

(19) Mustafa Reşit, Kuvvei kazaiye, IHFM, sene 5, 1927, sayı 32, s. 817 - 818 .

(20) Ch. Crozat, Devlet Şurasi: yasaya uygunluk mercii, Mülkiye Mecmuas,

(21) Talât Kâmil: Türkiy€de idar̂̂ nizamnameler, siyasal Bilgiler Mecmuasi, sayı 59, s. 46 - 48. - Bk. Keza Sarıca, s. g. e., s. $100-101$. 
söylenmektedir: "Nizamnameler hukuk kaideleri hiyerarşisinde kanunlardan sonra geldikleri ve bir nizamname kanunun hükmünü fesh ve tâdil edemiyceeği cihetle, hâkim bir hâdisede kanunla nizamnamenin taaruz etţ gön görse, nizamnamenin kanuna mugayeretine karar vermeksizin ve bunu iptal etmeksizin, nizamname ile fesih ve tâdile uğramayan ve kaideler hiyerarsisinde daha evvel gelen kanunu tatbik edebilir. Böyle bir vaziyette, hâkimin kararı nizamnamenin mevcudiyetini müteessir etrnez, ancak o hâdiseye tatbik edilecek hukukî hükmün ni-

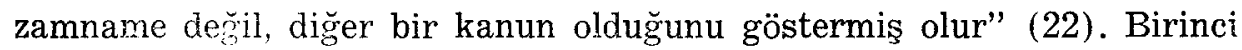
istisna olarą ileri sürülen sekil noksanı ile malûl tüzüğü bir tarafa blrakalım. İinci istisnayı ele alalım. Sayın Ord. Prof. S. S. Onar'a göre, hâkim ıüzü̧ün kanuna aykırılığına karar veremez; fakat kanuna aykırı olduğunu gördüğü tüzüğü ihmal ederek, kanunu tatbik edebilir.

Avıkat Gad Frankso Milâsh'nun "Hukukî Bilgiler Mecmuası" nda bu yazıya itiraz etmesi üzerine (23), sayın Profesör, uzun bir cevap vererek (24) tüzüklerin kanuna uygunluğunu mahkemelerin asla tetkik edemiyeceği fikrinde israr ediyor ve diyor ki: "Arkadaşım Milâslı, yalnız kanunla mukayyet olan hâkimin böyle bir nizamnamenin kanuna mugayeretine derhal karar vererek onu iptal edeceği kanaatindedir" (s. 5861). Hâkim nizamnameyi ne iptal edebilir; ne de kanuna aykırılığını tetkik edebilir; ancak "kanunun hükmü ile nizamnamenin hükmü ayrı ayrı olduğu takdirde" kanunu tercih ederek, nizamnameyi ihmal eder (s. 5898).

Ord. Prof. Sıddık Sami Onar, "İdare Hukuku" adlı büyük eserinin her iki basimında da aynı görüsse sadık kalmıștır: "Mahkemeler nizamnamelerin kanuna mugayeretini tetkik edemez. Bir nizamnamenin tetkiki esnasinda bunun kanuna mugayir olduğu iddia edilirse, idarî mahkeme de, adlî mahkeme de böyle bir iddiayı tetkike selâhiyettar değildir; olsa olsa bunu bir meselei müstehire sayarak böyle bir iddia dermeyan edene, selâhiyettar mercie, yani B. M. M. ne müracaat etmek üzere bir mühlet verir. Fakat doğrudan doğruya böyle bir iddiayı tetkik edemiyen mahkeme, kanunla nizamnamenin hükmü taaruz ettiği zaman kanunu tatbik etmek suretiyle nizamnameyi ihmal edebilir" (25).

(22) S. S. Onar, "Nizamname ve Talimatnameler", Izmir Baro Dergisi, sene 2, say1 $3-7$, s. $267-268$.

(23) G. Franko Milâslı, Bir tefsir hakkında, Hukukî Bilgiler Mecmuası, sene9, 15 temmuz 1938, no. 9 - 105, s. 5755 ve müt.

(24) Sıddık Sami Onar: "Nizamnamelerin kanuna mugayirliği iddiası karşısnda hakimin selahiyeti" Hukuki Bilgiler Mecmuası, sene 9, 15 ekim 1938, no. 12 - 108. s. 5855 ve müt. ve sene $10,15 \mathrm{Kasim} 1938$, no. $1-109$, s. 5888 ve müt.

(25) Idare $H_{u} k u k u$, C. I, ikinei bası 1945, s. 209. 
Görülüyor ki, Sıddık Sami Onar, kanun ile tüzük çarpıştığı takdir de kanuna itibar olunacağını kabul etmek suretiyle Muslihiddin Âdil beyin tezine yaklaşmaktadır. Fakat G. F. Milâslı, Sıddık Sami Onar'ın kullandığı şu ibareye haklı olarak takılmıștır: "Hâkim, nizamnamenin $k a$ nuna mugayeretine karar vermeksizin..." nizamnameyi ihmal edip kanunu tatbik edebilir. G. F. Milâsh ve Ragıp Sarıca, Sıddık Sami Onar's su suali sormakta haklıdırlar: Hâkim, mugayereti tesbit etmeksizin, hatta sayın Profesörün sık sık tekrarladığı gibi "mugayeret iddiasinı tetkik etmeksizin" nasıl olur da, tüzügü tatbikten imtina edebilir? Tiizügün kanuna aykırı olup olmadığını asla tetkik etmeden, nasıl olur da kanunla tüzük arasında mübayenet olduğunu görebilir?... "Hâkimin nizamnameyi tatbikten imtina etmesi için esbabı mucibesini anlatması şarttır". (26). Tüzüğün kanuna aykırı olduğu hiç bir tetkik yapmadan, "gökten inen bir ilham gibi... hâkime malûm ve zahir olamaz" (27). Bu itibarla, Sayın Ord. Prof. Siddık Sami Onar'ın kullandığr tabirler arasında telifi imkânsız bir tenakuz vardır.

Bu meselede ya Muslihiddin Âdil ve Ali Fuat Başgil gibi hâkimin kanuna aykırılık def'ini tetkik edip ona göre karar vereceğini kabul etmek lâzımdır; yahut da müderris Midhat ve $R$. Sarıca gibi hâkimin tüzük ile mutlak surette bağlı olduğu, her hangi bir tüzüğu tatbikten asla imtina edemiyeceği fikrini benimsemek gerektir.

Bizce, Suddık Sami Onar, "tatbik edemez", "mugayerete karar veremez" gibi tâbirler kullanmasına rağmen, esas itibariyle, defi yoluyla kazaî murakabe imkânını kabul edenler arasında sayılmalıdır. Zira, sayin Profesörün, bilhassa G. F. Milâsliya cevap verirken, "hâkim mugayeret iddiasını tetkik edemez", "mugayerete karar veremez" gibi tabirleri, daha ziyade "hâkim tüzüğü iptal edemez" manasında kullandiğını gösteren emareler vardır. Milâslı'ya verilen cevaptan aldı̆̆mız şu parçalar bu fikrimizi teyit etmektedir, sanırız: "...Ancak nizamnamenin kanuna tearuzunu, sakatlığını hangi merci, hangi usul ve sekiller dairesinde tetkik ve tesbit edecek ve ne suretle ortadan kaldıracaktır?. Dr. Milâslı, yalnız kanunla mukayyet olan hâkimin böyle bir nizamnamenin kanuna mugayeretine derhal karar vererek onu iptal edeceği kanaatındadır" (28). (Halbuki, birazdan göreceğimiz gibi, G. F. Milâslı, hâkimlerin iptal selâhiyetine malik olduğu fikrinde değildir ve profesörün İzmir Baro dergisinde çlkan ilk makalesine itiraz ederken de iptalden

(26) Gad Franko Milâsh: Mïnakaşalar: Kanun ve nizamname, Hukuki Bilgiler Mecmuası, 15 aralık 1938, sene 10 , sayı 2 - 110, s. 5917.

(27) Ragip Sarica, s. g. e., s. 114 - 115.

(28) Hukukî Bilgiler M., sene 9, 15 ekim 1938, no. 12 - 108, s. 5861. 
bahsetmemiştir). Yine ayni cevapta, Sıddık Sami Onar şunları yazıyor: "Meslekdaşıma göre, idarenin nizamname şeklinde tecelli eden bir tasarrufunun kanuna mugayereti iddiası da böyle kaza fonksiyonunu harek€te getirecek bir iddiadır. Hâkim bu iddia üzerine vazifesini ifa eder ve kanuna mugayir bulduğu tasarrufu iptal.... eder" (29). Yine bir başka yerde, Medenî Kanun ile tapu sicilli nizamnamesi, Borçlar kanunu ile Icar - Akar nizamnamesi arasinda mübayenet olursa kanunun tercih edileceğini belirterek şunları yazıyor: "Bu takdirde hâkim doğrudan doğruya kanunla hülimedeceğine göre, kaideler hiyerarșisinde nizamnameden evvel gelen kanuna istinad eden tarafa hak verir. Burada bir iptal dâvası ve hükmü bahis mevzuu değildir." (30)

Görüilüyorki, sayın profesörün itiraz ettiği fikir, daha ziyade, kanuna aykırı bir tüzüğü mahkemelerce iptal edilebileceği fikridir. Esasen bunu iddia eden de yoktur.

9 - Gerçekten , G. F. Milâslı da, hâkimin kanuna aykırı bir tüzüğü iptal edemiyeceğini kabul etmektedir. "Zaten hiç bir vakıt hâkimin mevzuattan birini iptal etmesi tasavvur edilemez." demektedir. (31) Esas itibariyle G. F. Milâsh'nın tezi, Muslihiddin Âdil'in, Prof. Basgil'in tezlerinden farklı değildir. Milâsh diyor ki : ( (S. S. Onar'a göre ..... hâkim kanuna tevíikan hareket edecek, fakat .... nizamnamenin kanuna mugayir olduğunu ağzina almayacaktır. Başka sözler ile sayın profesörün fikrini ifade etmek lâzım gelirse, mahkemeler böyle bir ihtimalde mübayeneti görerek tefsirde bulunacak, fakat teísir kelimesini kullanmı. yacak ve tefsirde bulunduğunu söylemiyecektir. Bence bu kaçamaklara. lüzum yoktur. Hâkimin önüne bir dâva geliyor. Bir taraf kanuna, diğer taraf nizamnameye dayanıyor; tabiîdir ki nizamnameye istinad eden taraf nizamname ahkâmının kanuna uygun ve diğer taraf aykırı olduğunu söylüyor. Hâkim bu münakaşada nasıl bitaraf kalabilir? Mutlaka hakkı takdirini, hakkı tefsir ve muhakemesini kullanarak " bu nizarr." name kanunu ihlâl ediyor; kanuna mugayir nizamnamenin tedvin edilemiyeceği Teşkilâtı Esasiyede yazılıdır. Bu nizamnameyi tatbik etmeyeceğim, reddediyorum" diye açıttan açı̆ga bütün istiklâli ile kanaatini söy* leyecektir." (32)

10 - "Esasiye Hukuku" adını taşıan eserinde, Osman Nuri Uman Büyük Millet Meclisinin kanuna aykırı bir tüzügü ortadan kaldırabileceğini belirttikten sonra, su suali soruyor: "Acaba mahkemeler de bu

(23) Ayni malcale, 3. 5861.

(30) Hukuki Bilgiler M., sene 10, 15 kasım 1938, no. 1 - 109, s. 5892.

(31) Hukukî Bilgiler M., sene 10, 15 aralik 1938, no. 2 - 110, s. 5917.

(32) Hukukî Bilgiler M., sene 9, 15 temmuz 1938, No. 9 - 105, s. 5760. 
hakka, yani bir nizamnamenin bir kanuna muhalif olduğuna hükmeylemek hakkına mâlik midir?" Osman Nuri Uman'a göre, "kanunlarımızda bu sualin sarih bir cevabı yoktur."; lâkin mahkemelerin kanuna aykırı bir tüzüğü tatbik etmemeleri daha doğrudur: "Bizce, bir kanunumuza konulmamıs, fakat o kanunun tatbik suretlerini gösteren nizamnameye girmiş olan cezanm mahkemelerce tatbik edilmemesi doğru olur. Çünkü bir fiile suç vasfıni vermek ancak teșri kuvvetinin selâhiyeti dahilinde olduğu gibi o fiil için tatbik olunacak cezayı göstermek, tâyin etmek de bu kuvvete aittir. Mahkemeler kanuna muhalif bir nizamnameyi de tatbik edemezler. Bn hususta kanun ahkâmına tâbidirler." (33)

11- Muhterem Ord. Prof. Ali Fuat Basgil, "Nizamname mefhumu" hakkındaki etüdünde, noktai nazarını hiç bir tereddüde mahal kalmıyacak şekilde, tam bir uzuhla açılamıştır. Muhterem âlime göre, Anayasamızın 52 nci maddesi sadece "nizamnamelerin kanunîliŏinin re'sen takdir ve mürakabesini Meclise birakmiștır." Tüzukler bizim hukuk sistemimizde, birer icra tasamuíu olduğuna göre, bunların re'sen takdiri ve mürakabesi de hâkime aìt olmak lâzımdır. Fakat kanun vazıı, tarihî sebeplerle, 52 nci maddenin son fikrasindaki hükmü sevkederek bu yolu kapamıştır. Sayın Profesör, bu fıkranın "hâkime karşı değil, icraî otoriteye karş1 " konmuş bir hüküm olduğunu belirttikten sonra, şunları yazıyor: "Binaenaleyh lâfziyle, ruh ve mânası ile, gaye ve maksadı ile kanunun lâfzına,ruh ve mânasına, gaye ve maksadına aykırı oỉan bir nizamname hükmü, hâkimi ilzam etmez. Hâkim önündeki bir dâvada tatbiki istenen bir nizamname hükmünün bir kanun hükmüne yahut umumî surette kanunî esaslara aykirı olduğuna kanaat edinirse, o hükmü tatbik etmez, kanunî esaslar dahilinde dâvayı halleder." (34)

İki faraziyeyi yekdiğerinden ayırmak lâzımđır:

a - “İdarî veya adlî mahkemede taraflardan biri filân nizamnamenin filân hükmüne istinad etmektedir. Diğer taraf buna, mevzuu bahsolan nizamname hükmünün filân kanunun filân hükmüne yahut 52 nci maddede nizamnamelerin mamulünbih olması için tâyin edilen esas şarta uygun olmadığı yolunda bir defi ile cevap vermektedir. Hâkim meseleyi tetkik eder. (Déni de justice) (35) hatasına düşmemek için tetkike mecburdur. Defi yoluyla vaki olan böyle bir iddia mahkeme için bir m:selei müstehire teşkil etmez. Hâkim 52 nci maddenin son fıkrasına binaen,

(33) Osman Nuri Uman, Esasiye Huknku, Ankara 1939, s. 100.

(34) Ali Fuat Basgil, s. g.e., (Hukukun ana mesele ve müesseseleri), Ist. 1946. s. $191-192$.

(35) thkakı haktan imtina. 
meselenin B. M. M. tarafından halline talikan hükmünü tehir edemez. B. M. M. hukuken mesul olmayan bir makamdır. Hâkim, hükmünü gayri mesul bir makamın cevabina tâlik edemez..." Binaenaleyh hâkim, meseleyi tetkike mecburdur. Neticede mugayerete kani olursa, nizamnameyi iptal etmez, bir tarafa bırakiır ve kanunu tatbik eder... Hattâ daha ileriye giderể diyeceğiz ki, hâkim önündeki bir dâvada tatbik edeceği nizamname hükmünün mugayeret iddiasını beklemeksizin bile kanuna uygun olup olmadığına dikkat edecektir." (36)

b -- İkinci faraziyede ise, bir dâva dolayısiyle değil, re'sen bir tüzüğün kanuna aykırılığını iddia etmek bahis mevzuudur. "Şûrayı Devlet, nizamnamelerin kanuna mugayereti hakkmda re'sen bir müracaat kabul edemez. Benim yapacağım is , 52 nci maddenin son flkrasına istisen iddialarm mercii halli T. B. M. M. dir."

tetkikini istemektir. Ne idarî ve ne de adlî mahkeme, nizamnamenin kanuna muage yereti hakkında re'sen bjr dâva kabul edemez. Bu yoldaki re'sen iddialarm mercii halli T. B. M. M. dir."

Sayın Profesörün fikirleri fazla izahata ihtiyaç göstermiyecek kadar açiktır.

12 - Türk idare hukukunun kendisine çok şeyler borçlu olduğu muhterem hocam Ragıp Sarıca, Prof, Basgil'in tezine tamamiyle muhaliftir. Sarıca, müderris Midhat beyin görüşüne iltihak etmekte ve gayet kat'î bir ifade ile, Türkiyede tüzüklerin kanuna uygunluğunu hiç bır sekilde kazaî murakabeye tâbi tutmak imkânı olmadığını ileri sürmektedir. 52 nci maddenin sarih olduğunu söyleyen sayın Sarıca șunu ilâve ediyor: "Biz kendi hesabımiza; bu maddeye göre nizamnamelerin kanunlara mugayeretini hiç bir suretle ve hiç bir hal ve vaziyette tetkike selâhiyettar olmadıkianına kani bulunuyoruz." (37) Hattâ, sayın müellife göre, bir tüzüğün kanuna aykırı olduğu iddiası bir meselei müstehire dahi teşkil etmez. (38)

Muhterem hocam R. Sarıca, profesör Crozat gibi, sadece kazaî mürakabenin imkânsızlığını ileri sürmekle kalmamış, bu iddiasını isbat yolunda bir çok mühim deliller de göstermiştir. Kendi kanaatımızı açılk. ladıktan sonra bu delilleri ayrı ayrı münakaşa edeceğimiz için, şimdilik Sarıca'nın fikirleri üzerinde durmayarak doktrinin tetkikine devam edelim.

13 - Ankara Üniversitesi Anayasa Profesörü sayın Bülent Nuri

(36) Ayni eser, s. 193.

(37) Ragıp Sarica, s. g. e,, s. 122.

(38) Ayni eser, s. 138. - Sarıca bu suretle Prof. Crozat'dan ayrılmış ve daha ileri gitmis olmaktadır. (bk. yukarda, bent 6 ). 
Esen, defi yoluyla kazaî mürakabenin mümkün olacağına kanidir. Hocamızın görüsünü sadakatle nakletmiş olmak için, 'Anayasa Hukuku' adlıeserin ilgili satırlarını aynen alıyoruz: "Hükûmetin .........tüzükler ç1karması, yürütme organının hukuk kuralı koyması demektir. Ancak, bu kurallar yeni hükümler seklinde ortaya çlkamazlar. Bir tüzügüun kanunla yasanmak gereken durumları karşılaması caiz görülemez. Şayet bir tüzük kanun hükümlerine .... göre değişik kurallar koymakta ise, yargıçların tüzük hükümlerini uygulamamaları icap edecektir. Gerçi; Anayasanın 52 nci maddesinin son fıkrası, tüzüklerin kanunlara aykırılı̆ı ileri sürüldükte bunun çözüm yeri T. B. M. M. dir, diye bir hüküm koymuş bulunmaktadır. Fakat, bu hükmü yargıcın belli bir dâvada bir tüzüğün uygulanamıacağını karar altına alamıyacağı manasında anlamamalıdır. Buradaki hükümden maksat, belki yargıcın genel kurallar şeklinde iptal kararları veremiyeceğidir." (39) "Tüzükler olsun, yönetmelikler olsun, hep hükûmetin iradesini anlatırlar. Hükûmetin kanunu ne yolda uygulamak icap edeceği hakkındaki düşünüş ve görüşui, yine ancak millî iradenin ifadesi olan kanuna uygun bulunmalıdır. Aksi halde, kanunlara göre hüküm vermek görevinde olan mahkemeler kanunu uygulayarak bu kanuna aykịı şekilde çıkarılmıș olan tüzükte yazllı hukuk kuralını bir tarafa birakırlar." (40)

14 - Kiymetli dostumuz doçent Bahri Savc1 da, " nizamnamelerin kanuniyetini kontrol hususunda Ali Fuat Başgil'in ve Muslihiddin Âdil beyin yaptığı tefrike uymak gerektiği" fikrindedir. "Vâkıa, 52 nci maddenin son fikrasının sarahatine göre, idarî ve adlî bir mahkeme önünde, bir nizamnamenin selâhiyet tecavüzünde bulunduğunu, kanuniyetsizlik ile malûl olduğunu, re'sen açlan bir dâva ile ileri sürmek mümkün değildir. Fakat kanunîyetsizlik ile malûl bir nizamname ile, adlî ve idarî bir mahkeme önünde takib edilen bir şahsın, defi yolu ile o nizamnamenin kanuniyetsizliğini iddia etmesi ve bunu hâkime tesbit ettirerek, meşrûiyet prensibine sığmayan o nizamnamenin kendisi hakkında tatbikini bertaraf ettirmesi yolu açıktır." (41)

15-Ankara Üniversitesi idare hukuku profesörü Süheyp Derbil "İdare Hukuku" adlı eserinde bu konuya temas etmiş, fakat iki tezden birine sarih olarak iltihak etmemiştir. Sayın Profesör "tüzük kanuna uygun

(39) Bülent Nuri Esen, Anayasa Hukuku, 3 üncü basım, Ankara 1948, s. 172 (ikinci basim, s.188).

(40) Ayni eser, s. 173 (tkinci basım, s. 189).

(41) Bahri Savc1, Devleti Hukuka Riayet Ettirme Vastalari, Siyasal Bilgiler Okulu Dergisi, 1948, C. III, say $3-4$, s. 25. 
olmak zaruretindedir. Kanuna aykırı olduğu iddiasını B. M. M. inceler" demekle iktifa etmislerdir. (42)

16 - Değerli hukukçularımızdan Dr. Halim Tevfik Alyot, 1947 yılinda Bern'de toplanan “Milletlerarası $\mathbf{I}$ darî Ilimler Kongresi” se sunduğu raporda, 'Türk mahkemelerinin tüzüklerin kanunlara aykırı olup olmadığı meselesini münakaşa edemiyeceklerini, bu selâhiyetin münhasıran Büyük Millet Meclisine ait olduğunu ileri sürmüștür. (43)

$\mathrm{Bu}$ suretle, incelemekte olduğumuz mesele hakkında Türk hukuk literatüründe rastlanan başlıca fikirleri hülâsa etmiş bulunuyoruz. Şimdi sıra kendi kanaatımızı ve bu kanaatın dayandığı mucip sebepleri izaha gelmiştir.

Bizce 52 nci maddenin tefsirinde Muslihiddin Âdil, G. F. Milâslı, Talât Kâmil, Prof. Başgil, Prof Esen ve doçent Savcı tarafindan yapılan tefriki kabul etmek lâzımdır. 52 nci maddenin son fıkrası bir tüzüğün kanuna aykırı olduğu iddiasıyla doğrudan doğruya Danıștaya başvurarak bu tüzüğìn iptalini istemek imkânını ortadan kaldırmaktadır. Fakat idarî veya adlî kaza mercilerinde görülmekte olan bir dâva mü nasebetiyle, hâdiseye tatbik edilecek bir tüzügün o kanuna aykırı olduğu taraflarca ileri sürülür veya hâkimin dikkatini çekerse mahkeme bu tüzüğün kanuna aykırı olduğuna pekalâ karar verebilir ve tüzüğü iptal edememekle beraber, o dâvada tüzük hükmünü tatbikten imtina edebilir. Hattâ daha ileri giderek diyebiliriz ki, hâkim, kanuna aykırı olduğuna kanaat getirdiği bir tüzüğu tatbikten imtina etmeğe sadece selâhiyetli değil, mecburdur. Bu iddiamızın dayandığı delilleri siraladıktan ve aksi tezi en etraflı sekilde müdafaa eden muhterem Sarıca'nın ileri sürdüğü delilleri ayrı ayrı münakaşa ettikten sonra kanaatımızı teyid eden bir kaç Yargıtay içtihadını nakledeceğiz.

Tüzükler hakkında ileri sürülecek kanuna aykırılık derinin mahkemeler tarafından kabul edilmesini müsbet hukuk ve mantık prensipleri bakımından zarurî ve hukuk siyaseti bakımından faydalı görüyoruz. Çünkü:

1 - Hukuk kaideleri hiyerarsisinde kanun tüzükten önce gelir ve bir tüzük kanunun hükmünü tâdil edemez. Hattâ 52 nci maddenin sarahatına göre, tüzük, açıktan açığa kanuna aykırı hukuk kaideleri koymais söyle dursun, kanunun derpiş etmediği yeni hükümler, yeni tahditler getiremez. Bundan başka, anayasamızda ve ceza kanununda tüzük le

(42) Süheyp Derbil, İare Hukuku, ikinci basım, Ankara 1948, s. 58.

(43) Halim T. Alyot, Les Tâches incombant à l'administration au lendemain de la Guerre Mondiale et les enseignements à tirer de l'expérience de cette guerre en matière administrative, $\mathrm{s} .7$ ). 
yeni vergi salınamıyacağını, hürriyetlerin daraltılamıyacağını, suç ve ceza ihdas edilemiyeceğini gösteren hükümler mevcuttur.

Bir tüzük Anayasanin 52 nci, 68 inci ve müteakip, 85 inci maddelerine veya Ceza Kanunun birinci maddesine aykirı olarak yeni hükümler ve mükellefiyetler, yeni vergiler, yeni suçlar ve cezalar ihdas edecek olur. sa, idarî ve adlî mahkemeler bu tüzüğe mutlak surette riayete nasıl mecbur tutulabilirler? Böyle bir durum karşısinda, tüzüğe riayet eden bir hâkim, dolayısıyla anayasaya ve tüzüğün ihlâl ettiği kanuna aykırı hareket etmiş olmaz mi? Bir mahkeme yekdiğerine açıktan açğa muhalif iki metin karşısında kalırsa, "ihkakı haktan imtina" edemiyeceğine göre, elbette bunlardan birini tercih ve diğerini - o dâvada - ihmal etmek mecburiyetindedir. Başka çlkar yol yoktur. Şu halde, bütün mesele hangi metnin diğerine tercih edileceği noktasındadır. Carpışan metinlerden biri kanun, diğeri tüzük olduğu takdirde, hâlimin tüzüğü daha üstün tutarak kanunu ihmal etmesi mümkün müdür? Böyle bir hal tarzl, umumî hukuk ve mantık prensiplerine aykırı olmakla kalmaz, tüzüğỉ kanuna tâbi kılan anayasamızın sarahatına ve ruhuna da aykırı düşer.

Bir hâdiseye hangi hukuk kaidesinin tatbik edileceğini araştırmak ve tatbiki mümkün olan hukuk prensiplerine göre muhtelif kaideler arasinda tercihler yapmak, mahkemelerin tabiî ve normal fonksiyonları arasındadır. Meselâ mahkeme yekđiğerini sarahaten ilga etmeyen, fakat birbirine zit hükümler taşıyan aynı kuvvette iki metinle karşlaşırsa, bunlardan daha yeni (muahhar) olanm tatbik eder. Bu, hiçbir yazll metinde yer almasa bile, umumî hukuk prensiplerinden çıkan tabiî ve mantıkî bir neticedir: "Leges posteriores priores contrarias abrogant".

Yekdiğeriyle çarpışan bir kanun ve bir tüzük karşısında ise, hâkirn elbette bunlardan hangisi daha yeni ise onu tercih ve tatbik edemez. Çünkü bir kanun kendinden önceki kanunu zımnen tâđil etmiş sayılabileceği halde, bir tüzüğün kendinden önce çikmış olan kanunu tâdil edebilmesi mümkün değildir. Bu itibarla, burada "leges posteriores" kaidesi aslâ cari olamaz. Bunun yerine hâkime rehberlik edecek ve iki metinden birini elindeki dâvaya tatbik etmesini mümkün kllacak başka bir hukuk prensibi vardır: daha kuvvetli olan metnin tercihi. Aksini ileri sürmek, anayasanın sarahatı hilâfına, tüzüğün bir kanunu zımnen tâdil ve ilga edebileceğini kabul etmek demektir.

2 - Bu duxum karşisında anayasanın 52 inci maddesinin son fikra. sını nasıl izah ve tefsir etmelidir?.. Kanaatımızca anayasanın 52 nci maddesinin son fikrası Sarıca'nın anladığı sekilde izah edilince, bu fıkra ile maddenin ilk flkrası arasinda bir tezat husule gelmektedir. Gerçek ${ }^{\uparrow} \cdot n$, Sarıànn izah şekli, mahkemeler bakımından, tüzüğün de kanun ka. 
dar kuvvetli olduğunu ve kanuna aykırı bir tüzüğün kanunun hükmünii tâdil etmiş, onun yerine kaim olmuş sayılacağını kabule münced olur. Halbuki, maddenin ilk filrrasında kanunun tüzüğe nazaran üstünlügü: ve bir tüzüğün kanunu tâdil etmek şöyle dursun, yeni hükümler getiremiyeceği açıkça ifade olunmuştur.

Bu çıkmazdan kurtulmak için, 52 nci maddenin son flkrasını yukarda izah ettiğimiz gibi anlamak ve hâkimlere kanuna aykırı bir tüzüğü tatbikten imtina selâhiyetini tanımak zarurîdir.

3-Prof. Crozat tarafından benimsenen "meselei müstehire"tezi de kabul edilemez. Prof. Başgil'in gayet haklı olarak belirttiği gibi, (44) hâkim, meselenin hallini B. M. M. ne bırakarak hükmünü tehir edemez. B. M. M. nin kararını bekleyemez. Çünkü B. M. M. hukuken gayri mes'ul bir makamdır. Bir dâvanın neticesi, gayri mes'ul bir makamın cevabına tâlik edilemez. Nitekim Sarıca da bu delilin kuvvetini kabul etmekte (s. g. e., s. 135) ve kanuna aykırılık definin meselei müstehire teșkil etmesi fikrini cazip görmemektedir. (45) Fakat unutmamak lâzımdir ki, meselei müstehire yolu da kapalı olunca şu iki şlktan birini tercih etmek zarureti vardır: ya hâkime bizim kabul ettiğimiz ölçüde murakabe selâhiyeti tanımak yahut da tüzügü kanundan üstün, hiç değilse kanuna eşit saymak.

4 - 52 nci madde ile tüzüklerin kanuna uygunluğunun kazaî murakabesi ancak kısmen daraltılmıştır. Sadece bir tüzüğün kanuna aykırılığını ileri sürerek Danıștayda iptal dâvası açmak imkânı ortadan kaldırılmıştır. Bu maddenin, Danıştay'ın yetkilerini gösteren 51 inci maddenin hemen arkasında yer alması da bu fikri teyid eden bir delil olarak ileri sürülmüştür. (46)

Bazı müellifler, mahkemelerin vazife ve selâhiyetlerinin kanunla gösterileceğini söyleyen 53 üncü madde ile 52 nci maddenin son fikrası arasında münasebet kurmak fikrindedirler. (47) 53 üncü madde, "Yargı Erki" başlı̆̆ını taşıyan 4 üncü bölümdedir. 52 nci madde ise daha önceki bölümde, yani "Yürütme Görevi" bölümünde yer aimıștır. Bu itibarla 52 nci maddenin, umumî mahkemelerden ziyade, icra uzvuna hitap eden ve onun selâhiyetlerini sınırlandıran bir madde olduğunu kabul etmek doğru olur.

(44) s. g. e., s. 193.

(45) ".... mugayeret iddiasının mahkeme için bir meselei müstehire teşkil edebileceğine de pek şüpheli nazarla bakıyoruz." s. g. e., s. 137). "bu gibi bir iddia ......... bir mese.lei müstehire teşkil etmemek gerektir." (. s. g. e., s. 138).

(46) Prof. B. N. Esen, s. g. e., s. 172.

(47) S. S. Onar, s. g. e., Hukukî Bilgiler Mecmuası, sene 10, 15 ikinci teşrin 1938, No, No. 109, s. 5899 - ve Sar1ca, s. g. e., s. 136 - 137. 
Uzvî bakımdan icraî bir karar mahiyetinde olan tüzüklerin, diğer icrâ̂ kararlar gibi Danıştay tarafindan tetkik ve iptal edilebilmesi daha tabî̂ ve makûl olurdu. Yukarıda gördüğümüz gibi, netice itibariyle hâkimlerin kanuna aykırı tüzükleri tatbikten imtina edeceklerini kabul eden S. S. Onar dahi, 52 nei maddenin "nazarî bakımdan sert" olduğunu belirtmektedir. (48) Prof. Başgil ise, 52 nci maddedeki hükmün sadece tarihî sebeplere dayandığını izah ettikten sonra, bu fikranın hâkimlere karşı değil, daha ziyade icra uzvuna karşı itimatsızlık ifade ettiğini söylemektedir. Bu fıkranın mânası, "Teşkilât Kanunu vazının hâkimlere karşı beslediği bir itimatsızlık değil, Türkiye tarihinde hemen daima ceberrutî bir kuvvet gibi hareket etmiş olan icraî makamları bizzat B. M. M. nin yedi zaptında bulundurmak ve hükûmetin Meclise tâbi bir organ olduğunu bir kat daha tebarüz ettirmektir." (49) "Vâzı kanun bu hükmü hâkime karşı değil, icraî otoriteye karşı koymuştur. Hükûmeti bizzat kendi eli ve kontrolü altında tutmak istemiştir." (50)

Demek ki, 52 nci maddenin son fikrasından, mahkemelerin defi yoluyla mürakabede bulunmaların dahi önleyen tam ve mutlak bir memnuiyet mânası çıkarmak bu bakımdan da yerinde değildir.

5 - Sayın Sarıca, mahkemelerin, kanuna aykırı olup olmadıklarını tetkik etmeksizin, bütün tüzükleri harfiyen tatbik etmeleri lâzımgeldiği tezini ispat için meseleyi terminoloji cephesinden ele alıyor. Sarıca'ya. göre" 52 nci maddenin son fikrasında mutlak bir ibare kullanılmıştır: "Nizamnamelerin kavanine mugayereti iddia olundukta bunun mercii halli T. B. M. M. dir." "İddia" kelimesi yalnız re'sen dâva, re'sen iddia, re'sen müracaat mânasına kullanılmaz. Bu kelime hem dâva, hem de defi mânasına kullanılır. Anayasanın ibaresi her iki hale de şâmildir.

Derhal itiraf edelim ki, gercekten, 52 nci maddenin son fikrası "iptal dâvası" ile "kanuna aykırılık defi" (exception d'illégalité) arasında açık bir tefrik yapmamıștır. Fakat şunu da ilâve edelim ki Türk Hukuk terminolojisi "iddia" kelimesini mutlak surette şu veya bu mânada tefsir etmeye imkân verecek derecede tebellür etmiş ve kesinleşmiş değildir. Fıkranın mânasını ve şumulünü sadece "iddia" kelimesine dayanarak tâyin etmemize imkân yoktur. Esasen, hukukta "lâfzi tefsir" her zaman doğru neticeye ulaştırmaz. 52 nci maddenin son fikrasını tefsir ederken yukarda izaha çalıştığımız hukuk prensiplerini ve maddenin ilk fıkrasını da göz önünde tutmak gerektir. Bu fıkradan, mahkeme.

(48) Hukukî Bilgiler Mecmuası, sene 10, 15 ikinci teşrin 1938 no. 1 - 109, s. 5896.

(49) Ali Fuat Basgil, s. g. e., (Hukukun ana mesele ve müesseseleri), s. 185.

(50) Ayni eser, s. 191. 
lerin kanuna aykırı tüzükleri dahi tatbike mecbur olduğu neticesini çıkarmak, hem mantığa ve umumî hukuk prensiplerine, hem de maddeniu ilk fikrasına aykırı düsmektedir. Kaldı ki, Anayasayı yapanların irade. sini tefsir ederken, Meclis müzakerelerine de bakmak lâzımdır. İlerde göreceğimiz gibi, bu müzakereler, bizim görüşümüzü teyid etmektedir.

6 - Muhterem R. Sarıca, ikinci delil olarak, "mahkemelere bir tüzüğün kanuna aykırı olup olmadığını araștırmak selâhiyetini tanımamız ne hukukî, ne de siyasî bakımdan doğru olmaz" demektedir. (s. 125! "Hukukî bakımdan doğru olmaz" hükmünü teyid için yine bundan önceki bentte bahsettiğimiz terminolojik delili tekrarlamaktadır. Hukuk Siyaseti bakımından böyle bir murakabenin zararlı olacağı yolundaki iddiaya gelince, bunun üzerinde biraz duralım:

Sarıca'ya göre, resen yapılacak aykırıllk iddialarını Meclis tetkik edeceğine göre, defi yoluyla tetkik selâhiyeti mahkemelere verilecek olursa, ayni tüzük hakkmda Meclis bir türlü, mahkeme başka tür. lü karar verebilir. Meselâ Ali ile Veli arasındaki bir dâvada, Veli bir tüzüğün kanuna aykırı olduğunu ileri sürüyor. Mahkeme bu iddiayı hakIt bularak ve Prof. Başgil'in tezini benimsiyerek, hâdiseye tüzüğü değil, doğrudan doğruya kanunu tatbik ediyor. Ayni mahiyette bir hâdisedeu doğan bașka bir dâvada ise, ayni tüzüğün kanuna aykırılığ 1 ileri sürü. lüyor. Bu defa, mahkeme - Prof Midhat ve Crozat gibi düșünerek - aykırılık iddiasını tetkik etmiyor. Bunu hir meselei müstehire sayarak, aykırılık iddiasını ileri süren tarafa, Meclise müracaat etmesi için mühlet veriyor. Meclis de tüzüği kanuna uygun buluyor. Bu suretle, ayn: mahiyetteki iki hâdisede iki ayrı karara varımıș oluyor. Bu mahzuru belirttikten sonra, Sarıca, aykıriluk iddiasınn münhasıran bir tek merci tarafından tetkikine taraftar olduğunu söylüyor.

Muhterem Sarica'nın ileri sürdükleri bu delil süphesiz hemen yabana atılamaz. Fakat, münhasıran hulkuk siyasetine dayanan bu delilin, kendilerinin çok bağlı oldukları 'pozitif hukuk görüž̋̆" bakımından büyük bir kıymet taşıdığ 1 süuphelidir.. Saniyen, tasavvur edilen mahzur, ilk bakışta zannedilebileceği kadar mühim değildir. Gerçekten, sayın müellifin verdiği misallerde șu esaslardan hareket edilmektedir: birinci mahkeme bizim - Ali Fuat Başgil'i takiben - müdafaa ettiğimiz tezi kabul ediyor ve tüzüğü tatbik etmiyor. Ikinci mahkeme ise, Prof. Crozat gibi düsünerek, aykırıllı iddiasını "meselei müstehire" sayıyor. Bu suretle iki farkin neticeye varllyor. Fakat, bizim tezimiz kabul edildidiği takdirde Meclisin kararı ile mahkemelerin kararları arasında çatıșma olacağını isbat etmek bakımından bu misaller bizi ilzam etmez. Çünkü, biz esasen bu mahkemelerden yalnız birincisine hak veriyoruz. Ikin- 
ci mahkemenin tuttuğu yolu hatalı görüyoruz. Aykırılık iddiasının bir "meselei müstehire" sayılmasını ve Büyük Millet Meclisinin kararını beklemek üzere dâvanın tehirini yersiz buluyoruz. Nitekim, Sarıca da ayni şekilde düşünmektedir. (Bk. Sarıca, s. g. e., s. $137-138$; yukarda. 3 numaralı bende de bakmız).

Demek oluyor ki, Sarıca'nın verdiği misallerin bizim tezimizle doğrudan doğruya alâkası yoktur. Fakat ayni itiraz bize karşı da ileri sürülebilir ve denebilir ki: bir "meselei müstehire" bahis mevzuu olmaks!zın, doğrudan doğruya, re'sen Büyük Millet Meclisi'nden bir tüzüğün kanuna aykırılı̆̆ı hakkında karar istenebileceğini kabul ediyorsunuz. Bu takdirde de mahkemenin kararı ile Meclisin kararı arasında çatısma olması mümkün değil midir?

Bir kere, Meclis mahkemeden önce karar vermişse ,böyle bir çatışma ihtimali aslâ mevcut değildir. Meclis tüzüğü kanuna aykırı bulduğu takdirde, tüzük iptal edilmiş ve bağlayıcı kuvvetini kaybetmiș demelktir. Mahkemeler artık o tüzüğü tatbik edemezler ve Meclisin kararı ile mahkemelerin kararı arasında bir çatısma olamaz. Aksine, Meclis tüzügün kanuna uygun olduğu yolunda bir karar ittihaz ettiği takdirde, yire mahkemelerin kararı ile, Meclisin kararı arasında bir çatışma mutasavver değildir. Meclis böyle bir karar vermekle âdeta kanunu tefsir etmiş, "tüzük kanunun mâna ve maksadına uygundur" demiştir.

İkinci ihtimali düşünelim: mahkeme Meclisten önce karar vermiștir. Bir dâvada bir tüzüğün kanuna aykırılığı ileri sürülmüș ve mahkeme tüzüğü kanuna aykırı bularak tatbik etmemiştir. Daha sonra da Meclis̄ ayni tüzüğün kanuna uygun olduğuna karar vermiștir. Böyle bir ihtimalin - zayıf dahi olsa - mevcudiyeti bizim tezimizi çürütmeğe kâfi gelir mi? Hayır... Ayni durum bir kanunun tefsiri halinde de mevcut değil midir? Bir mahkeme, bir kanunun maddesini kendi anlayışı'a göre tefsir edip, bakmakta olduğu hâdiseye tatbik etmiştir. Daha sonra her hangi bir milletvekilinin talebi üzerine, Meclis ayni maddeyi bambaşka bir sekilde tefsir edemez mi? Buna bakarak, " mahkemeler kanunları tefsir edemezler; aksi halde mahkemelerle Meclis arasında çatıșma olur" diyebilir miyiz? Mahkemelerden kanunları tefsir selâhiyetini almak, onların elini kolunu bağlamak neticesini doğurmaz $m ı$ ?.. Tüzüklerin kanurlara aykırılı̆̆ını tetkik bahsinde de vaziyet aynidir. Bu selâhiyeti mahkemelere vermemek, bizi yukarda izah ettiğimiz gibi çlkmaza sokar, mantıksız neticelere götürür. Aşağıda göreceğimiz başka mahzurlar da dogurur. Anayasa 52 nci maddesinin son fikrasinda "Tüzüklerin kanurlara aykırılığı ileri sürüldükte bunun çözüm yeri Türkiye Büyük Millet Meclisidir" dediği gibi, $26 \mathrm{nc}$ maddesinde de “..... kanunları yorumla- 
mak görevini Büyük Millet Meclisi ancak kendisi yapar" hükmüni koymustur. "Kanunlarm tefsirini bizzat Biiyük Millet Meclisi yapar" hükmünden nasıll mahkemelerin bu işi yapamıyacakları neticesini çlka ramıorsak, 52 nci maddenin son fıkrasından da mahkemelerin tüzük. lerle kanunlar arasındaki mutabakatı tetkik edemiyeceği neticesini çkaramayız. (51) Ancak, nasıl mahkemelerin tefsirleri - teşriî tefsirden farklı olarak - yalnız baktıkları dâvaya münhasır ise, tüzükler hakkındaki kararlar da - Meclisin kararlarından farklı olarak - sadece o dâvaya, o hâdiseye maksur ve münhasırdır. Kanuna aykırı bulduğu bir tüzüğii tatbikten imtina eden hâkim, normal fonksiyonunu, vazifesini ifa etmiştir. 'Tüzüğü ihmal etmek suretiyle, kanunu ve en iptidaî hukuk prensiplerini ihlâl etmekten kurtulmuștur.

7 - Sayın Ragıp Sarıca, üçüncü delil olarak, tüzüklerin "hükûmet tasarrufları" olduğunu ileri sürüyor. Buradan da, tüzüklerin her türlï kazaî mürakabeden masun kalmaları lâzımgeldiği netices'ni çıkarıyor. Sarıca diyor ki: "...... kanunun her hangi idarî bir tasarrufu kazaî mura. kabe dișında tutması onu bir hükûmet tasarrufu telâkki ettiğini gös. terir... Binaberin mahkemelexin bir tasarruf üzerinde kontrollerini kul. lanmadıkları görülürse bu tasarrufun bir hükûmet tasarrufu olduğuna teredoütsüz hükmedebiliriz." ( $s . g . e .$, s. 131). "Anayasanin nizamnameleri bir hükûmet tasarrufu addettiği kuvvetle iddia olunabilix" (s. g. e.. s. 131).

Muhterem hocamızın bu fikrine de iştirâlk edemiyeceğiz. Bizce, tüzüklerin birer hükûmet tasarrufu olduğu iddiası yeni bir delil olmaktan ziyade, daha önce gördügümüz delillerin bir bașka şekilde tekrarından ibarettir. Münakașa konusu olan nokta zaten șudur: Anayasa kazâ̂ mercileri tüzüklerin kanunlara uygunluğunu tetkikten mutlak surette men'etmis midir?.. - Evet, diyor, Sarıca, men'etmiștir, çünkü tüzüklen birer hükûmet tasarrufudur. Fakat tüzüklerin hükûmet tasarrufu olduğu hükmü nereden çlkarılıyor? Buna da "tüzükler birer hükûmet tasarrufudur, çünkü anayasa bunlar üzerinde kazaî murakabeyi men'etmiştir." diye cevap veriliyor. Hülâsa burada bir isbat (démonstration) değil, sadece bir iddianın (affirmation) başka şekilde tekrarı bahis mevzuudur; bir fâsid daire vardır.

Muhterem müellif "mahkemelerin bir tasarruf üzerinde kontrollerini kullanmadıkları görülürse, bu tasarrufun bir hükûmet tasarrufu ol-

(51) Yirmi altinc maddenin eski metninde "bizzat kendisi" ve yeni metninde "ancak kendisi" ibareleri mevcut olduğu halde 52 nci maddede böyle bir kayıt dahi yoktur. Buna rağmen, 26 nes maddeden "kazaî tefsir"in memnu olduğu neticesini çlkarmałk kimsenin aklına gelmemiştir. 
duğuna tereddütsüz hükmedebiliriz" dediklerine göre, Yargıtayın aşağıda göreceğimiz içtihatları karşısında, tüzükleri birer hükûmet tasarrufu saymak hususundaki tereddüdümüzü mazur göreceklerdir.

Kaldı ki, tüzüklerin hükûmet tasarrufu sayılması başka bakımlar. dan da tenkid edilebilir. Tüzükler hiçbir ileri hukuk devletinde kazaî murakabeden tamamiyle ve mutlak surette muaf tutulmuşlardır. Tüzükler mahiyetleri itibariyle kazaî murakabeye elverişli olmayan tasarruflar değildir. Bizdeki "hükûmet tasarruflarl" mefhumunun beşiğ: olan Fransada, tüzüklerin kanunlara uygun olup olmadığı hem defi yoluyla, hem de hattâ Devlet Şûrasında doğrudan doğruya iptal dâvası açmak suretiyle murakabe edilir.

Sayın Sarıca buyuruyorlar ki: "Bu pek yabana atılır bir fikir olmąsa gerektir. Çünkü umumiyetle hükûmet tasarruflarının çoğu için varit olan bir mülâhaza nizamnameler için de aynen varittir.Filhakika.......hükûmet tasarruflarının ekserisi - hükûmetin parlâmento ile müanasebeti. pârlamentoca tasdik olunan muahedeler, meclisin müdahalesini zarurî rî kılan tasarruflar .... - mahkeme ile meclis (parlâmento) arasında muhtemel fikir ayrilıklarina, mübayin kararlara mani olmak için kazaî murakabeden muaf tutulmuşlardır." (s. g. e., s. 132 - 133). H€men söyleyelim ki, hükûmet tasarruflarma misal olarak gösterilen sıkıyönetim, yabancı devletlerle yapılan anlaşmalar ve hükûmetin parlâmento ile münasebetleri gibi tasarruflarla tüzükler arasinda derin farklar vardır. Hükûmet sıkıyönetim ilân edẹ etmez bu kararını Meclisin tasdikine sunmağa mecburdur. Meclis toplantı halinde değilse hemen toplanmaya çağrılır ( Anayasa, m. 86). Bu itibarla, sikıyönetim kararı mutlaka ve sarih surette Meclisin murakabesinden geçer. Verilen diğer misallerde de hal böyledir. Yabancı devletlerle yapllan andlaşmalar da mutlaka Meclisin tasdikine sunulur ve sarih bir murakabeye tâbi tutulur. Tüzüklerin Meclis tarafindan mutlaka murakabe ve tasdik edileceğine dair anayasamızda bir kayıt olmadığı gibi fiiliyatta da Meclsin 52 nci maddeye göre haiz olduğu murakabe selâhiyeti müessir sekilde kullanılamamaktadır. Vatandaşların, anayasanın 52 nci maddesine dayanarak, bir tüzüğün kanuna aykırılığını tesbit etmesi için Meclise dilekçe ile ile başvurdukları görülmemektedir. Şu halde, sıkıyönetimde veya andlaşmaların tasdikinde olduğu gibi, kazaî murakabeyi lüzumsuz ve imkânsız kılan müessir bir Meclis murakabesinden bahse. dilemez.

Esasen, sayın Sarıca'nın burada yeniden ileri sürdüğü "Meclisle mahkemelerin çatışması" mahzurunun sanıldığı kadar mühim olmadığını bundan önceki bentte izaha çalışmıs̆tık. "Meclişle çatışmak ihtima- 
li mahlremeleri durdurmalıdır" yolunda bir iddia, mahkemeleri - Meclis tarafından belki tasdik edilmez endișesi ile - ölüm cezası vermekten de, hattâ kanunların tefsirinden de alıkoymak neticesine müncer olur. Halbuki bizim huliuk nizamımız hâkimlere yalnız kanunları tefsir etmek değil, kanunlarda boşluk olduğu takdirde kendisi kanun vazl1 imiş gibi hüküm vermek selâhiyetini bile tanımıştır. ( Medenî Kanın, m. 1).

Tüzüklerin hükümet tasarrufu sayılması fikri su balkımdan da tenkide şayandır: hükûmet tasarrufları - taraftarlarının iddialarına göre - mahiyetleri itibariyle önceden konmuş hukuk kaidelerine bağlanmaları ve binnetice kazaî mürakabeye tâbi tutulmaları mümkün olmayan tasarruflardır. Bunlara hukuk kaidelerinden ziyade siyasî düşünceler hâkimdir. Tüzüklerin ise mahiyetleri itibariyle hukuk kaidelerine bağlanamyacak tasarruflar olduğu aslâ ileri sürülemez. Bil'âkis her tüzük bir kanuna bağlıdır ve bu "kanunun uygulanışnı göstermek yahut kanunun emrettiği işleri belirtmek üzere" yapılmıştır. Şu halde tüzük yapılırken bu kanunun koyduğu kaideler göz önünde tutulmalı ve ihlâl edilmemelidir. Halbuki hükûmet tasarruflarını kazaî murakabe dışında bırakmak için, bu tasarrufları yaparken önceden konmuş bir txkım kaideleri gözönünde bulundurmağa imkân olmadı̆̆ ileri sürülür. (52)

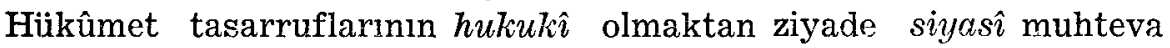
taşıyan tasarruflar olduğu hususunda fazla israr edecek değiliz. "Les actes de Gouvernement" adlı klâsik eserinde, Prof. Paul Duez bu ciheti açıkça göstermiştir. (53)

(52) Nitekim bizzat $R$. Sarıca da, başka bir kitabında hükûmet tasarruflarını tarif ederken ayni kistası ileri sürmektedir. (talarî Kaza, tstanbul 1942, s. 47). Sarica, (Türk Devlet Şûrası kararlarina göre Hükâmet tasarrıflari) başlıklı bir makaiesinde (IHFM, 1943, Cilt VIII, sayı 3 - 4, s. 457) bizdeki hükumet tasarruflarının listesini yapmıs, fakat tüzükleri bu listeye ithal etmemiştir. Çünß: tüzükleri sarih surette hükûmet tasarrufu olarak vasıflandıran içtihatlar mevcut değildir. Sarıca'ya göre, "sırf hukuk tekniği bakımından hangi tasarrufların bir: : hủkamet tasarrufu sayılması lâzımgeldiğini söylemek hukuken imkânsızdır" ( $s$. $a$. e.., s. 472). O halde neye istinaden tüzüklerin birer hükûmet tasarrufu olduğu ön sürülüyor?.. Sarıca, hükamet tasarruflarını ayırmağa yarayacak hị bir kıstas mevcut olmadığı için, hükamet tasarruflarına müteallik mahkeme içtihatlarının hukuken tenkid edilmesi imkânsız, her türlü tenkitten mâsan içtihatlar olduğuna da kânidir (s. g. e., s. 472). Biz muhterem hocamızın bu fikrine iştirâk etmemekle beraber, tlizükler hakkındaki mahkeme içtihatlarının - yazının sonunda göreceğimiz gibi - bizim tuttuğumuz tezi takviye ettiğini bir kere daha belirtelim.

(53) Bk. Paul Duez, Les Actes de Gouvernement, Paris, 1935, s. 23 ve müt.; bk. keza., S. S. Onar, s. g. e., s. 260.-

Esasen Danıştayımızın birçok kararlarında da hükûmet tasarrufları "siyasi mahiyet tasıyan" tasarruflar olarak vasıflandırılmıştır. Bk. meselâ Birinci Dava Dai- 
Son olarak, hukuka bağlı devlet sistemi içinde, hükûmet tasarruflarının esasen göze batan bir rahne tesgil ettiğini hatırlatmak isteriz. Hükûmet tasarrufları nazariyesinin beşiği sayılan Fransada olsun, bizde olsun, hükûmet tasarrufları kategorisinin kalkması ve bu tasarrufların "takdir selâhiyeti" mefhumu icerisinde eriyip kaybolması yolunda bir cereyan vardır. Hocamız Prof. Siddık Sami Onar, hükûmet tasarruflarının takdir selâhiyeti içinde eriyị ortadan kalkmasını hararetle terviç edenler arasındadır. Hiç bir tasarrufun mutlak surette kazaî murakabe dışında tutulmasi doğru olmaz. Hattâ muahede akdi gibi tamamiyle siyasî mahiyet taşıyan bir tasarruf bile bazı bakımlardan kazaî murakabeye tâbi tutulabilir. "Hükûmet tasarrufları nazariyesi takdir selâhiyetine istinad ettirilince, bir taraftan hükûmet faaliyetleri için lâzım gelen serbestî temin edilmekle beraber, diğer taraftan bu nazariyenin kaza sisteminde husule getirdiği karışılıklar, hukukî tasarruflar nazariyesinde doğurduğu anormal vaziyetler, idare edilenlerin hak ve selâhiyetleri bakımdan arzettiğg tehlikeler kalkmış olur". (54). Paul Duez de, adı geçen eserinde, hükûmet tasarrufları fikrinin ortadan kalkması icab ettiğini ve takdir selâhiyeti nazariyesinin maksadı temine kâfi olduğunu isbat etmistir. Profesöre göre, bir hukuk devletinin müesseseleri arasında hükûmet tasarruflarına yer yoktur. (55) Şu halde, sayın Sarıca'nın tüzükleri hükûmet tasarrufu saymak suretiyle kazaî murakabenin dıșinda tutmağa çalışması doğru değildir.

8 - Tüzüklerin kanuna uygunluğunun mahkeme tarafından defi yoluyla murakabe edilebileceği tezine karşı ileri sürülen itirazlardan biri de şudur: mahkemeler yüzlerce, binlerce dâvada bir tüzüğü tatbikten imtina ederlerse, tüzük fiilen iptal edilmiș olmaz mı? Bir tüzügün kanuna aykır olduğu yolunda müstakar bir ictihat teessüs edince artık o tüzüğün hukukî kıymeti kalır mı?.. "Mahkemeler tüzüğü iptal edemezle", fakat kanuna aykırı görürlerse baktıkları dâvada tatbikten imtina edebilirler" seklindeki tefrik sun'î bir tefriktir. Tüzüğün iptal olunması ile tatbikinden imtina edilmesi arasinda fark yoktur. (56)

$\mathrm{Bu}$ itiraz da varit değildir. Bir tüzük aleyhine doğmıdan doğruya

resi, 29/2504, Pavli Naskidof - Maliye Vekâleti, Kararlar Mecmuası, sayı 6, s. 122; Beşinci Daire, E. 38/6, 39/182, Mansur Karabıyılk - Dahiliye ve Słhhat Vekâletleri, Kararlar Mecmuasi, sayı 8, sayfa 85 - 86; Besinci Daire, E. 37/2241, K. 39/290, Emin Arslanoğlu - Dahiliye Vekâleti, Karartar Mecmuası, sayı 9 , sayfa 70 - 71; Dava Daireleri Umumî Heyeti, E: 40/290, K. 43/83, Tevhidi tçtihat Kararı, Kararlar Mecmuá$s l$, sayı 24 , sayfa 34 .

(54) S. S. Onar, s. g. e., s. 262.

(55) Paul Duez, s. g. e., s. 185 - 210.

(56) Sarica, Icra uəvunun tanzim selahiyeti, s. 134. 
iptal dâvası açılması başka şey; yekdiğeri ile çarpışan iki metin kar\$1sında kalan bir mahkemenin bunlardan kuvvetli olanmı (yani kanunu) tercih ederek tüzüğü ihmal etmesi bașka şeydir. İptal kararı, tüzüğü objektif surette, herkes için ortadan kaldıracağı halde, "tatbikten imtina" sadece o dâvada hüküm ifade eder. Bu farkı inlâr etmek, iptal dâvaları ile tam kaza dâvalarının - doğurdukları neticeler bakımındanfarklı olduklarını inkâr etmek gibidir. "Iptal" kararı vermekle "tatbikten imtina etmek" arasında, psikolojik bakımdan da fark olduğu ve ikinci seklin daha az göze battlğı birçok müellifler tarafından iddia olunmuştur. (57)

Gerçi, mahkemelerin devamlı ve müstakar içtihatları bir tüzüğ̈̈i fiilen kiymetsiz burakabilir. Fakat bundan, iptal etmekle etmemek arasında hiç fark bulunmadığı neticesi çıkarılamaz. Müstakar görünen bir içtihat günün birinde değişebilir.

Medenî kanunumuzun birinci maddesiyle yargı̣ca verilen selâhiyet yalnız bakmakta olduğu dâvada hüküm ifade etmek üzere bir hukuk kaidesi yaratmaktır. Bu kaide ne diğer mahkemeleri, ne de hattâ ayni yargıcı başka dâvalarda bağlamaz. Fakat bütün mahkemelerin mümasil vaziyetlerde hep ayni sekilde karar vermeleri, fiilen müstakar bir kaide tesis etmeleri de kabildir. Buna bakarak, Medenî Kanunun birinci maddesiyle yargiçlara verilen selâhiyetin yasama kuvvetinden farks1z olduğu iddia edilebilir mi ?..

Esasen, muhterem Sarica da, "nizamnamenin iptal edilmesiyle ip. tal olunmaması arasında bir fark müsahede etmek hemen hemen imkânsız olur" (58) demek suretiyle, iki şılk arasında cüz'î de olsa bir farkm mevcudiyetini kabul etmektedir. Bu tefrikin amelî kıymeti ne olursa olsun, tüzüklerin kanuna uygun olup olmadıklarının "dâva yoluyla" murakabesi ile "defi yoluyla" murakabesi arasinda fark olduğu muhakkaktir.

9 - Sayın R. Sarıca, Prof. Başgil'in delillerini münakaşa ederken, tüzüklerin kanuna aykırılığını tetkikten imtina etmenin "ihkakı haktan imtina" sayılamıyacağını söylüyor. "Mevzuatın, pozitif hukukun sarahaten bir dâva mevzuu teşkil edemiyeceğini belirttiği bir dâvayı dinlememek bir (déni de justice) telâkki olunamaz" diyor (s.g.e., s.136).Bir tüzügün kanuna aykırılı̆̆ sebebiyle iptalini istemek suretiyle açılan bir dâvayı reddetmek, hiç süphesiz (ihkakı haktan imtina) sayılamaz. Bu

(57) Bk. meselâ Duguit, Leçons de droit public général, Paris, 1926, s. 288 -289; Manuel de droit constitutionnel, 4 ème éd., Paris 1923, s. 304; C. Al. Viforeano, Le contrôle constitutionnel des lois, Mélanges Negulesco, Bucureşti 1935, s. 832-833

(58) Ragip Sarica, s. g. e., s. 134. 
noktada R. Sarıca haklıdur. Fakat esasen biz mahkemelerin iptal dâvalarına bakmaları lâzımgeldiğini ileri sürmüyoruz. Bir mahkeme, bakmakta olduğu bir dâvaya tatbiki icap eden kanunla tüzük arasında mïbayenet görürse, tüzüğ̈ tatbikten sarfınazar etmelidir. Zira, mahkeme için şu üç yolun dışında gidilebilecek başka bir yol yoktur:

a) Mahkeme dâvayı tehir edip, Büyük Millet Meclisinden meselenin hallini istiyecektir. İşte bu takdirde (ihkakı haktan imtina) durımuna düşebilir. Çünkü Büyük Millet Meclisi mesul olmayan bir makamdır; cevabını alabildiğine geciktirebilir veya hiç cevap vermiyebilir. Esasen, gördüğümüz gibi, R. Sarıca da bu yola gidilmesine taraftar değildir.

b) İkinci yol, R. Sarıca'nın tavsiye ettiği yoldur ki, tüzüğü kanuna tercih etmek; zaylf bir hukuk normunu kaideler hiyerarşisinde kendisinden daha önce gelen hukuk normuna üstün tutmak gibi bir neticeye müncer olmaktadır: bu netice ise kanaatımızca mantıksızdır.

c) Üçüncü yol, burada müdafaa ettiğimiz yoldur: Mahkemenin kanunu tüzüğe tercih ederek, elindeki dâvayı kanun hükümleri dairesinde halletmesidir.

10-Hukuk kaidelerinin tefsiri hususunda, Meclis müzakerelerinden de faydalanmak lâzımdır. 52 nci maddenin müzakeresi sırasında, B.M.M. hassasiyet göstermiştir. Tüzüklerin kanuna aykırı olamıyacağı prensibine verilen ehemmiyeti isbat eden sözler sarfedilmiştir.

Tüzüklerin muteber olmaları için gerekli șartları gösteren birinci fıkraya, Mersin mebusu Besim Beyin teklifi ile "ahkâmı cedideyi muhtevi olmamak" kaydı ilâve edilmiștir. (59) Bu ilâve "kanunlara aykırı olmamak" kaydından daha şümullü, daha ağırdır. Diğer bir âzâ ( Tevfik Fikret Silay) mazbata muharririnden sunları sormuştur: "Bu nizamat mahakimde mamülünbih midir; bu nizamatın herhangi maddesi mucibince mahkeme hükmedebilecek midir?" Mazbata muharriri Celâl Nuri Beyin, gerek sual sahibini, gerekse Meclisi tatmin ettiği anlaşlan cevabi aynen sudur: "Kanuna mugayir olduğu takdirde hükkâm bununla amel edemez" (60). Hâkim "nizamname ile âmel edemediğine" göre ne yapacaktır? Elindeki hâdiseye kanun hükümlerini tatbik edecek, kanunu tüzüğe tercih edecektir.

Mazbata muharririnin bu sarih beyanı karşısında tereddüt caiz değildir. Sayın Ragıp Sarıca, Celâl Nuri Beyin bu sözünü de kendi tezine ci celse).

(59) Zabıt Ceridesi, Cilt 8/II, s. 1007 (Devre II, 42 nci içtima, 20-4-1340, birin.

(60) Zabit Ceridesi, ayni cilt, ayni sayfa. 
göre tefsir etmiştir. Muhterem müellife göre, mazbata muharriri burı söylerken "ağlebi ihtimal B. M. M. si nizamnamenin kanuna mugayir olduğunu tesbit ettiği takdirde artık hâkim bununla âmel edemez dọmek istiyor." ( s. g. e., s. 141 ) Bizce Celâl Nuri Beyin beyanatinı bu şekilde anlamak çoğru değildir. Çünkỉ Meclis tarafndan kanuna aykırılığı tesbit edilen bir tüzük esasen hukukî klymetini kaybeimistir, bir tüzük olmaktan çıkmıştır. Celâl Nuri Bey " kanuna aykırı nizamname" derken, herhalde, B. M. M. tarafindan ilga edilmenis olan, fakat kanun. aykırılığına mahkemece kanaat getirilen tüzükleri kastetmiṣ olmalıdır.

11 - Sayin Sarica, hâkimlere isterlerse tüzüğü tatbik etmek, isterlerse tatbik etmemek seklinde bir hiyar hakkı tanınamıyacağını, çünkü böyle bir salâhiyetin tüzüklerin mecburî, emperatif mahiyeti ile telif edilemiyeceğini söyliuyor (s. 145 - 146).

Bizce, bu iddia meselenin mihverini değigtirmektedir. Çünkü biz tüzüklerin prensip itibariyle mahkemeler için "mamulünbih" olduğunu, tatbiki mecburî, emperatif kaideler ihtiva ettiğini inkâr etmiyoruz. Hâkime "bir nizamnameyi canı isterse tatbik etmek, canı istemezse tatbilk etmemek" seklinde mutlak bir hiyar hakkı tanımması bahis mevzuu değildir. Hâkim 52 inci maddedeki şekle ve esasa müteallik bütün şżrtara uygun olarak yapllmıs bir tüzüğü tatbik etmeğe mecburdur. Falrat "kanuna aykır" olduğuna kanaat getirdiği bir tüzüğu ihmal etmek de yine hâkim için vazifedir. Cünkü aksi takdirde kanunu (ve Anayasanın 52 inci maddesinin ilk fikrasinı) ihmal etmiş olacaktır.

Bizim tezimiz sudur ki, kanunla tüzüğün çatıştığım gören bir hâkim için hiyar hakkı yolitur: Kanunu üstün tutacaktır. Halbuki mukabil tez şu neticeye müncer olmaktadrr: "Hâkimin hiyar hakkı yoktur; tüzüğü kanuna tercih edecektir." Bu neticenin mantıksızlığı ise aşikârdır. kats

12 - Muhterem Ragıp Sarıca'nın ileri sürdüğ̈ başka bir delil de şudur: "Hâkimi bağlamıyan bir nizamnamenin neye yarıyacağ̀ da câyi sualdir...... öyle ise nizamname neye yarar? Hukuk âleminde ne gibi bir rol oynar? Her kanun gibi, her nizamname de tatbik edilmek icin tanzim, tedvin olunmaz mı?" (s.g.e, s. 147). Evet, hiç şüphesiz tüzülkler tatbik edilmek için tedvin olunur. Yalniz memleketimizde değil, başka memleketlerde de "tüzükler tatbik edilmek için tanzim olunur". Yazımızın ilk kısmınđa gördüğümüz gibi, ileri hukuk nizamlarında, mahkemelerin kanuna aykırı tüzükleri tatbikten imtina edebilecekleri münakaşa konusu olmaktan çımıştır. Bununla beraker, o memleketlerde hiç kimse "ma-

(60) Zabit Ceridesi, ayni cilt, ayni sayfa. 
demki mahkemeler icabında kanuna aykırı bir tüzüğ̈i tatbikten imtina edebiliyorlar, o halde tüzük yapmak neye yarar?" diye sormamıştır. Cünkü, Anayasanin koyduğu esashı bir şartı yerine getirmemiş olduğu için bir tüzüğün tatbik edilmemesi demek, icra uzvunun tanzim salâhiyetinden beklenen bütün faydanın yok olması demek değildir. Muhterem Sarıca'nın bu mütalâasına iştirak etmek imkânsızdır. Zira, "mademki Danıştay idarî kararları iptal edebiliyor, o halde idarenin bir takım kararlar ittihaz etmesi neye yarar?" diye sormakla yukardaki delil arasında pek fazla fark yoktur.

13 - Sarıca'ya göre, tüzüğün kanuna uygun olup olmadığı hususunda hâkimin edindiği kanaat hukukî bir kıymet taşımaz: "Hâkimin bu yoldaki kanaati - tıpkı kanunî bir delil ile isbatı lâzımgelen bir hususta olduğu gibi - hukuken rol oynamaz. Hâkim, nizamnamenin kanuna aykırlığına yüzde yüz kanaat getirse bile bu kanaata huikuken itibar olunamaz. Nasıl bir hâkimin meselâ onbin liralık bir dâvada resmî senet, kaziyei muhkeme, yemin... dışında herhangi bir delil ile kanaat getirmiş olması hiçbir hukukî netice tevlit etmez."

Muhterem hocamın bu görüşüne de hak veremiyorum. Istinat ettiği sebepler tamamiyle başka olan "kanunî delil" usulï ile meselemizin bir ilgisi yoktur. Hâkimin, kanuna aykırı olduğuna yüzde yüz kanaat getirdiği bir tüzüğü tatbik etmesi demek, yalnız şahsî kanaatini feda etmesi demek değildir: kanunu da, Anayasanm 52 nci maddesinin ilk flkrasını da, hukuk mantığını da, birçok hallerde ferdî hürriyeti de tüzüğe feda etmesi demektir. 52 nci maddenin son fikrasının, tüzüklere bütün bunlarm üstünde bir kıymet izafe ettiği iddia olunabilir mi?

14 - Muhterem Sarıca'nın ileri sürdüğu başka bir delil (s.g.e., s. 148 - 151), tüzüğe âdeta kanunun üstünde bir kuvvet bahşeder gibi görünen bundan önceki mütalaalarmm menşeini ve mesnedini açılamaktadır. Sarıca'ya göre tüzük, kanumun serhi, tefsiridir. Tüzük, kanun maddesini "tıpkı bir tefsir kararı gibi" şerh ve izah eder. Bu bakımdan "hâkim nazarında nizamname ile kanunun tearuz etmesi, çarpışması mutatasavver değildir" (s. 149). "Nizamnamede yer alan kaideyi âdeta $k a-$ nunda yer almış saymak lâzımdır" (s. 150). "Nizamname kanuna nazaran hem muahhar bir hukuk kaidesi vazeder, hem de maddei kanuniyenin bir tefsiridir. Bu tefsir bizzat bu kanun yerine kaim olmaktadı"' (s. 151). "Nizamnamenin kanuna aykırılı̆ı mülâhazası ile hâkimin nizamnameyi ihmal etmesi hukukan mümkün değildir. Nasıl ki hâkim iki kanun karş1sinda dả muhayyer değildir .Muahhar olanı, diğerini tamamlayanı tatbike mecburdur" (s. 151). 
$\mathrm{Bu}$ sözler her şeyi izah etmektedir. Bundan önceki bendlerde gördüğumüz gibi, kanunu tüzükten iistün, tüzükten önce gelen, tüzükten daha kuvvetli bir hukuk kaidesi olarak nazarı itibara alınca, Sarıca'nın tezi hukuk mantığını kabul edemiyeceği neticelere müncer olmaktadir. Muhterem müellif de bunu çok iyi görmüs olsa gerektir lri, tezini müdafaa edebilmek için, nihayet tüzüğe kanunla müsavi, hattà kanundan üstün bir kuvvet izafe etmek mecburiyetini duymuştur. Bu iddiasm teyid hususunda da Profesör Başgil'in etüdünden bazı kısımlar nakletmektedir.

Fakat tüzüğun kanuna müsavi ve hattâ muahhar olması dolayısiyle âdeta kanundan üstün bir kuvvet taşıdığ iddiası asla kabul edilemez. Kaideler hiyerarșisinde tüzüğün kanundan sonra gelen bir yer jşgal ettiği ve kanuna tâbi olduğu şüphesizdir. Tüzük ne kanun kuvvetini, ne de teşriî bir tefsir kuvvetini haiz olamaz.

tki kanun arasında aykırılık olduğu takdirde, bunlardan daha sonra çıkmış olanı öncekini zımnen ilga veya tâdil etmiş sayı̉ı. Kanuna aykırı bir tüzüğün de - tıpkı muahhar bir kanun gibi - önceki kanunu zımnen ilga veya tâdil ettiği nasıl ileri sürülebilir? Bir kanun tüzük ile ilga edilebilir mi? "Leges posteriores priores contrarias abrogant" kaidesi burada tatbik olunabilir mi? Bunu kimse iddia edemez. Şu halde tüzüğü kanunla müsavi kuvvette saymak, hele "muahhar bir kanuna" benzetmek tamamiyle yersizdir (61).

Tüzüğun kanunla ayni seviyede mütalâa edilmesi nasıl mümkün olabilir ki, yukarda da temas ettiğimiz gibi, Anayasamız birçok maddelerinde kanunla tüzüğü sarahaten ayırmiştır. Anayasanin 85 inci maddesi verginin ancak kanunla salınabileceğini, tüzük ile yeni vergi ihdas edilemiyeceğini gösterir. Hürriyetlerin de tüzük ile daraltılamıyacağı, ancak kanunla sinırlandırılabileceği Anayasada musarrahtır. Tüzük ile suç ve ceza ihdas edilemiyeceği de malûmdur (Türk Ceza Kanunu, madde 1).

"Tüzük ile kanunun çarpışniasının mutasavver olmadığı" yolundaki

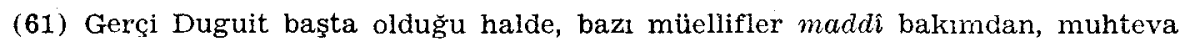
bakımından kanunla tüzük arasında bir mahiyet farkı bulunmadığını iddia etmişlerdir. Hauriou, Berthélemy, Carré de Malberg başta olmak üzere, diğer bazı miiellifler de bu teze karşı cephe almışlardır. Fakat bu iddiaların bizim tezimizle alâkası yoktur. Çünkü, "Duguit de dahil olduğu halde, hiç kimse kanunun tüzükten daha üstün olduğunu, tüzülklerin kanunlara aykırı olamiyacağını, kanunların tüzükle tâdil edilemiyeceğini inkâr etmemiştir. Tưzüklerin kanunlara aykırı olup olmadıklarının mahkemelerce murakabesi tezine Duguit de hararetle taraftardır. (Bu münakaşaya dair mủcmel malûmat almak için şu eserlere bakılabilir: Bonnecase, (s.g.e., s. 137 - 143; Berthélemy, La loi et le règlement, Mélanges Hauriou, s. 821 - 825; Carré de Malberg, Contribution à la théorie générale de l'état, cilt I, s. 568). 
iddiayı ise, bizzat 52 inci maddenin ilk fıkrası, tüzügün yeni hükümler getiremiyeceğini söylemek suretiyle, sarahaten tekzip etmektedir. Tüzükleri "tefsir karar" yla bir tutmak da tamamiyle yersizdir. Tefsir, bir kanunun hükmünün mânasını tayin etmek demektir. Kanuna aykırı olan, meselâ kanunun hiç ihtiva etmediği yeni suçlar, cezalar, vergiler, tahditler ihdas eden, kanunun hükmünü tâdil veya tevsi eden bir tüzük nasıl tefsir kararına benzetilebílir?

Bizce, Muhterem R. Sarıca'nın idarî bir tasarruftan ibaret olan (62) tüzükleri "muahhar bir kanun", "teşriî bir tefsir" gibi mütalâa etmesi, şuna delâlet eder: Sayın müellif, benimsediği tezin, ancals bu faraziyeye dayanmak suretiyle müdafaa edilebileceğini, derin görüşü ile herkesten daha iyi kavramıştır.

15 - R. Sarıca, adlî mahkemeler, tüzüklerin kanunlara uygunluğunu murakabe ettişleri takdirde idarî mahkemelerden de bu salâhiyetin esirgenmiyeceğini belirtiyor (s. 152 - 154). Muhterem müellif iddiasında haklıdır. Fakat; idarî mahkemelere de ayni salâhiyetin tanınması zarureti tezimizi çürüten bir delil olamaz. Bunda idare hukukunun umumî prensiplerine aykirı bir cihet de göremiyoruz.

İdarî kaza ile adlî kaza ayrılığının çok kökleşmiș olduğu Fransa'da, tüzüklerin kanuna uygun olup olmadığının gerek adlî, gerek idarî mahkemeler tarafından murakabe edildiğini unutmamak lâzımdır. Fransa hukukçuları ve mahkemeleri bu meselede "kanunun hâkimiyeti" prensibi ile "kuvvetlerin ayrılığı" prensibini bağdaștırmışlardır (63). Bir tüzüğün kanuna aykırılığının Danıstay tarafindan defi yoluyla tetkiki evvelemirde o tüzüğün iptalini de icap ettirmez. Fransada, 60 günlük müddet geçtiği için artık aleyhine iptal davası açlamıan bir tüzüğün kanuna aykırı olduğu, görülmekte olan bir dâva münasebetiyle def'an dermeyan edilebilmekte ve bu suretle iki murakabe şekli yekdiğerini tamamlamaktadir (64).

16 - Muhterem Ragıp Sarıca son delil olarak şunu ileri sürüyor: "Mahkemelerin bir nizamnamenin kanunla tearuz ettiğini gördükleri takdirde... nizamnameyi ihmal edebilmeleri ve kanunu tatbik eyleyebilmeleri

(62) R. Sarıca, eserinin başka bir bahsinde, nizamnamelerin teşriî bir vekâlete dayandikiarı tezini kuvvetle tenkid ederek, nizamnamelerin uzvî bakiımdan birer idarî tasarruf. olduklarını fakat sırf "hüikümet tasarrufu" sayıldıkları için kazaî murakabe dışnda kaldıkların belirtmektedir (s.g.e., s. 250 ve uot).

(63) Bk. Achille Mestre, s.g.e., s. 578 ve müt.

(64) Bk. meselâ; Bonnecase, s.g.e., s. 143; A. Mestre, s.g.e., s. 591. 
bizi çok uzaklara götürür. Şöyle ki ayni muhakemeyi kanunlamn Esas Teşkilât Kanununa aykırılığı hususunda da yürütebiliriz." "52 inci maädenin... hâkimin bir nizamnameyi bir tarafa birakıp kanunu tatbik etmesini tecviz ettiğini kabul edersek, bunun aynen kanunlar için de böyle olacağını kabul etmemiz iktiza eder. Yani 52 inci madde mucibince alelâde bir kanunun Anayasa ile çarpıştığını gördüği takdirde hâkim, kanunu bir tarafa bırakarak doğrudan doğruya Anayasayı tatbik edebilir."

Hocamazn ba fikrine tamamen iștirak ediyoruz. Gercekten, kanuna aykırı bir tüzüğün mahkemeler tarafindan ihmal edilebileceğini kabul edince, ayni muhakemeyi Anayasaya aykırı kanunlara da teşmil etmek zarurîdir. Fakat bu hakikat, bizim müdafaa ettiğimiz tezi zayıflatamaz. Olsa olsa, kanuna aykırı tüzüklerin ihmalini caiz gördükleri haIde Anayasaya aykırı kanunlarm mahkemeler tarafindan ihmali fikrini reddeden miielliflerin tenairuza düstuiklerine delâlet eder. Biz, Anayasaya aykırı kanunların defi yoluyla kazaî murakabeye tâbi tutulabileceği fikrinde olduğumuz için sayın Ragıp Sarıca'nın ileri sürdüğü bu delili, tezimizi cerh değil, teyideden bir delil olarak karşllyyoruz. "Kanunlarm Anayasaya uygun olup olmadığının kazaî murakabesi" meselesine dair yakında neşretmeyi umduğumuz bir etüdde bu konuya tekrar döneceğimiz için, şimdilik üzerinde daha fazla durmıacağız.

Yazımıza son vermeden önce, birkaç Yargitay içtihadından bahsedelim:

Ceza Umumî Heyetinin 4.11.1935 tarihli bir içtihadı, tezimizi açıça teyit etmektedir. Bu kararda, Fuhuşla mücadele nizamnamesi ile Ceza Kanunu arasıria bir mübayenet bahis mevzuudur. Karar, Hukukî Bilgiler mecmuasında, Adliye Ceridesinden naklen, hülâsa edilmiștir: "436 ncı maddenin tatbiki o maddede mevcut unsurlarin tahakkukuna menut olup aksini kabule Ceza Kanununun birinci maddesinin mâni bulunmasına ve nizamnameler, kañun hükümlerine aykırı olarak yeni hükümler vazedemiyecekleri Teşkilâtı Esasiye Kanununun 52 inci maddesi ile müeyyet olmasina ve binaenaleyh işbu nizamnamenin 107 inci maddesinde Ceza Kanununun 436 ncı maddesi hükmüne aykırı suç unsurları ihdas ettiğini kabul etmeğe imkân olmadığına ve bu halde nizamnameye göre yapılan takibat neticesinde sabit olacak fiil hakkında yine taallûk ettiği kanun maddeleri mucibince ceza verilmesi hem Tesskilâtı Esasiye, hem Ceza Kanununun kabul ettiği prensiplere uygun olamiyacağından yazll emirle talep edilen nakz talebinin varit olmadığına karar verilmiş ve bașmüd- 
deiumumilikçe heyeti umumiyeye itiraz edilmiş ise de itirazı vâki de tasvip edilmiyerek reddolunmuștur" (65).

Yine ayni mevzuda, 4 üncü ceza dairesinin 1944 de verdiği başka bir karar, Yargıtayın aradan geçen dokuz yıl zarfında içtihadını değiştirmediğini isbat ediyor: "Tendilerini başkalarmin cinsî zevkine, menfaat mukabilinde veya itiyadî bir surette hasretmeği sanat ittihaz eden ve bu suretle müteaddit erkeklerle münasebette bulunan kadınlara fahişe denir. $436 \mathrm{ncl}$ maddede yazılı fuhşa teşvik suçu, yirmi bir yaşım bitirmeyen kadınların fuhuş yapmasını maddî manevî kolaylaştırmaktır. Fuhuş ile meluf "fahişe" olanin fuhşa teşvikinden bahsedilemez. Fuhiş̧la mücadele nizamnamesinin Ceza Kanununu tevsi veya tâdil eden hükümleri muteber değildir” (66).

Bu kararların her ikisinde de, kanuna aykırı bir tüzüğün mahkemece tatbik edilmeyip bir tarafa birakılacağı prensipi hiçbir şüpheye mahal birakmiyacak şekilde ifade olunmustur. Fakat her iki kararın da ceza hukukuna muiteallik olması bazı kimseleri tereddüde sevkedebilir. Yargıtayın yalnız kanuna aykırı bir sekilde suç ve ceza ihdas eden tüzükleri tatbikden imtina ettiği zehabına düsülebilir. Bu tereddỉaü de izale etmek için Ticaret dairesinden çıkan diğer bir kararı da nakledelim:

Bir kimse sahip olduğu bir geminin yüzde elli hissesini satmıstır. Fakat bu satış resmî șekilde yapılmamıștır. Satışın tescili yolunda alıcilar tarafından yapılan talep, İstanbul Liman İdaresi tarafından, "satış, Türk gemilerinin tescili hakkındaki tüzüğün 3 üncü maddesinde tasrih edildiği gibi tescile esas olabilecek resmî sekilde tanzim edilmemiştir" gerekçesi ile reddolunmuştur. Satıcı da bizzat liman idaresine gidip takrir vermeğe yanaşmamıştır. Bidayet mahkemesi, tescilin icrası yolunda alıcılar tarafından açllan davayı, adı geçen tüzüğ̈̈n 3 ncü maddesine müsteniden reddetmiştir. Yargıtay ticaret dairesi ise, gemi satışının kanunen hiçbir şekle tâbi tutulmadığını ve sıhhati kanunen muayyen bir şekle bağlanmamış olan bir hukukî muamelenin bir tüzük ile sihhat noktasından muayyen bir şekle bağlanamıacağını belirterek, kararı bozmuştur. Kararın en özlü kısminı aynen naklediyoruz: "Deniz Ticaret Kanununun 1015, 1016 nc1 maddeleri gemi veya payının satışın özel bir şekle tâbi kılmamış olmasına ve Anayasaya göre kanun hükümlerinin uygulanma tarzın gösteren

(65) Ceza Umumî Heyetinin 4.11.1935 tarihli karart, Hukukî Bilgiler mecmuası, 15 haziran 1937, No. 8 - 92, s. 5362, (Adliye Ceridesi, No. 12, Ceza kararları s. 56 dan naklen).

(66) Dördüncï Ceza Dairesi karar 4.4.1944, esas: 1894 (bk. Faruk Erem, Gcrekçeli Türk Ceza Kanunu ve meriyet kanunu, Ankara 1946, m. 436, not 4). 
tüzükler kanun hükümlerini hiçbir suretle takyid edemiyeceğine ve Borçlar Kanununun 11 nci maddesinde akdin slhhati kanunda sarahat olmadıkça hiçbir șekle tâbi olmadığı beyan olunmasına göre, olayda satış sözleşmesinin note ̌̉likçe yapılmamış ve dâvalı satıcının da liman idaresine gidip takrir vermeyip keyfiyeti bir dilekçe ile bildirmiş olması Deniz Ticarế Kanununun 1015, 1016 ncı maddeleri hükümlerine uygun olarak yapılan ve dâvalı vekili tarafından karşılık dilekçede ve yargılama sırasinda da ikrar ve kabul olunan satıș bağıtının hükümsüzlüğünü gerektirmez". (67).

Ankara Hukuk Fakültesi Ticaret Hukuku Ordinaryüs Profesörü Ernst Hirs de Ticaret Kanunu ile Tescil Nizamnamesi arasindaki mübayenet karşısında, kanunu tercih etmek lüzumuna kanidir: “... Yukarda belirttiğimiz üzere bir gemi üzerindeki hakkın intikali şekle bağlı değildir... Mazhar Nedim Göknil, resmî şekli akdin bir unsuru saymakta ve bu görüş tarzını Tescil Nizamnamesinin üçüncü maddesine dayandırmaktadir. Ticaret Kanununun 1015 ve 1016 ncı maddeleri çok açık olduğundan ve muamelenin slhhatine müteallik kanunî bir hüküm nizamnamede bulunan ve yalnız isbata yarayan bir hükme herhalde tekaddüm ettiğinden, adı geçen müellifin görüşü kabul olunamaz" (68).

Kararlar Dergisinde, Danıştayımızın bu konudaki görüşïnü vuzuhla açıklayan bir karara rastlamadık. Fakat bugüne kadar yayınlanmamış olan bir beşinci daire kararı, tüzükle kanun çarpıştığı takdirde kanunu tercih etmek fikrine Danıştayımızın da bigâne kalmadığını göstermektedir. Hâdise şudur: Konyada bulunan bir kimseye 7 haziran 1939 tarih ve 3634 saylı Millî Müdafaa Mükellefiyeti Kanunu tatbik ediliyor. Bu kanunun birinci maddesi şöyledir: "Umumî veya kısmî seferberlik halinde ve fevkalâde hallerde yapılacak seferberlik hazırlıkları ile kıtaların tecemmüleri esnasında, alelâde vasitalarla temin edilemeyen bütün askerî ihtiyaçları veya hizmetleri bu kanunun hükümleri dairesinde vermeğe veya yapmağa her şahıs borçludur. Bu mükellefiyetlerin Türk topraklarının tamami veya bir kısmı üzerinde yapılmasına başlanacağı zamanı Icra Vekilleri Heyeti tayin eder'. Bu kanunla ilgili olarak 22 haziran 1940 tarihli bir tüzük neşredilmiştir (69). Bu tüzüğün birinci maddesi de aynen șudur: "Umumî veya kısmî seferberlik halinde ve fevkalâde

(67) Yargntay Ticaret Dairesi, Esas 945/2593, Karar 2036. (Adalet Dergisi, Şubat 1946 Yargitay kararları, Hukuk bölümü, s. 19).

(68) E, Hirş, Ticaret Hukuku Dersleri, tst. 1946, s. 763 - 764.

(69) Millî Müdafaa Mükellefiyeti Nizamnamesi, Resmî Gazete, sayı 4546, 27 haziran 1940. 
hallerde yapılacak seferberlik hazırlikları ile kıtaların tecemmüleri esnasında, alelâde vasıtalarla temin edilemiyen bütün askerî ihtiyaçlar veya hizmetleri Millî Müdafaa Mükellefiyeti Kanunu ile buna müstenit işbu nizamname hükümleri dairesinde vermeğe ve yapmağa her şahıs borçludur. Millî Müdafaa Mükellefiyetinin tatbikına başlanacağı ve nihayet bulduğu tarihler ve bu mükellefiyetin tatbik sahası lera Vekilleri Heyetı karariyle tayin ve ilân olunur".

Görülüyor ki, tüzüğün birinci maddesinin ikinci cümlesi kanundan hafifçe farklıdır. Kanunda mükellefiyet sahasının Bakanlar Kurulunca tayin olunacağı söylenmekle iktifa edildiği halde, tüzükte ayrıca bir de ilân'dan bahsedilmektedir. Konyalı vatandaş, "Millî Müdafaa Mükellefiyetinin Konyad'a tatbik edileceğine dair Bakanlar Kurulu tarafından bir karar ittihaz edilmiş ise de, bu karar ilân edilmemiştir" diyerek hakkında yapılan muamelenin iptalini istemiştir. Konya Valiliği ise savunmasında kanuna dayanmiştır. Gerçekten, kanun hükmü tatbik edilirse idarenin kararına diyecek yoktur; tüzük tatbik edildiği takdirde ise kararın iptali lâzımdır.

Beşinci dairenin kararında bu mesele şu șekilde halledilmiștir: “... Bakanlar Kurulu kararı ile mükellefiyetin sahası taayyün etmiş olup bunun ilân edilmemiş olması kanunun güttüğü amaca ve hizmetin niteliğine göre kanunun yürürlüğe girmesine engel olacak bir hüküm sayılamiyacağından ilân edilmemek sebebine dayanllarak kanunun yürürlüğe konulmadığı yolunda dâvacı tarafından ileri sürülen defi de varit bulunmamaktadır" (70). Görülïyor ki, Daniștayımız bu hâdisede kanunu tüzüğge tercih ederek tüzügün hükmünü bir tarafa birakmıştır.

Netice olarak diyebiliriz ki, Türkiyede tüzüklerin hiçbir kazaî murakabeye tâbi olmadığı tezi mahlremeler tarafından da kabul edilmemiștir. Türkiyede, tüzükler aleyhine doğrudan doğruya iptal dâvası açlamaz; fakat Türk mahkemeleri, bakmakta oldukları bir dâvada kanunla tüzügüun çarpıştığını görürlerse, kanunu tatbik edip tüzügü bir.tarafa bırakırlar.

(70) Beşinci Dairenin E: 44/172, K: 45/385 sayılı ve $7 . I I I .1945$ tarihli karar.Mamafih, yine Konyada cereyan eden müşabil bir hâdise dolayısiyle altıncı dairenin aksi istikamette karar vermiş olduğunu da söylemeğe mecburuz: Altıncı Dairenin 23.10.1947 tarihli kararı, E: 46/1530; K: 47/1851, Bilâl Kırımlılar - Konya Valiliği. Her ikisi de yayınlanmamış olan bu iki kararı bana vermek lûtfunda bulunan çok degerli kanun sözcüsü sayın Mehmet Nomer'e burada teşekkür etmeyi borç bilirim. 